\title{
SPATIOTEMPORAL CHARACTERISTICS AND THE INTERSPECIFIC COMPETITION OF PHYTOPLANKTON IN TIEGANG RESERVOIR (CHINA)
}

\author{
SONG, Y. L. ${ }^{1}-$ ZHU, J. ${ }^{2}-$ WANG, L. $^{3}-$ TAO, Y. ${ }^{4}-$ GAO, J.S. ${ }^{1}-$ ZHANG, J. S. ${ }^{1 *}$ \\ ${ }^{1}$ School of Civil and Environment Engineering, Harbin Institute of Technology, Shenzhen \\ 518055, China \\ ${ }^{2}$ School of Architectural and Environmental Engineering, Shenzhen Polytechnic, Shenzhen \\ 518055, China \\ ${ }^{3}$ Shenzhen Water Quality Testing Center, Shenzhen 518055, China \\ ${ }^{4}$ Graduate School at Shenzhen, Tsinghua University, Shenzhen 518055, China \\ *Corresponding author \\ e-mail: 562045128@qq.com
}

(Received $19^{\text {th }}$ Feb 2019; accepted $1^{\text {st }}$ May 2019)

\begin{abstract}
Chlorophyll a concentration [ $\rho(\mathrm{Chla})]$ in phytoplankton is used to understand algal biomass and the primary productivity of a water body. To investigate the seasonal dynamics of $[\rho(\mathrm{Chla})]$ and their relationship with environmental factors Tiegang Reservoir at Guangdong China, continuous observation and analysis was carried out from April 2013 to June 2014. The distribution of algae had an obvious spatial heterogeneity, and the $\rho($ Chla) gradual increased from the southeast to the northwest of the reservoir. From April to early December 2013 and from late April to June 2014, the dominant algae was cyanobacteria. In other months, bacillariophyta were dominant. Chlorophyta were at a low level throughout the year. Multivariate analysis showed that water temperature (WT) was the primary driving factor of the spatio-temporal distribution of algae. The main environmental factors of cyanobacteria, bacillariophyta and chlorophyta were greatly different. Single environmental factors such as WT, total organic carbon (TOC), nitrate nitrogen $\left(\mathrm{NO}_{3}--\mathrm{N}\right)$, and chemical oxygen demand (COD) were significantly related to the competitiveness of cyanobacteria and bacillariophyta. And they can be used as early warning indexs for cyanobacteria and diatom blooms. The dual synergistic effects of WT and other environmental factors on the competitiveness of cyanobacteria and bacillariophyta were analyzed. A combination of environmental factors at high risk for cyanobacteria or diatoms were found.
\end{abstract}

Keywords: chlorophyll a, environment factors, seasonal variation, multivariate analysis, interspecific competitiveness

\section{Introduction}

Shenzhen is the most densely populated city in mainland China. At the beginning of its establishment, the total population was 320,000 (Liu et al., 2013; Gu and Ma, 2013; Qin et al., 2014; Ng et al., 2011; Zhou et al., 2011). As of the end of 2016, the actual population had increased to 18 million, and the population density reached 9,015 persons $/ \mathrm{km}$, ranking first among the cities in mainland China. The influx of a large immigrant population placed unprecedented pressure on the water supply system and seriously polluted the water environment (Liu et al., 2013; Gu and Ma, 2013; Qin et al., 2014; Ng et al., 2011; Zhou et al., 2011). Although Shenzhen is located in the subtropical region, no large rivers or lakes exist in the territory. Therefore, rich rainfall cannot be effectively gathered, resulting in scarce water resources. So Shenzhen is experiencing a serious water shortage (Güneralp and Seto, 2008; Liu and Ma, 2011). In 
2015, nearly $90 \%$ of the city's drinking water needed to be imported from the Pearl River. Shenzhen water supply system is mainly composed of overseas water diversion engineering and local reservoirs. There are nearly 168 reservoirs in Shenzhen. After arriving at Shenzhen, overseas water was firstly stockpiled in local reservoirs and then was supplied to nearby water works. Therefore, water quality of those reservoirs has played an important role to the city's drinking water security. And how to ensure the safety of drinking water and to meet the people's increasing requirement for the quality of drinking water became important topics in the construction of ecological civilization in Shenzhen (Liu et al., 2013; Li et al., 2015; Lu et al., 2015).

Chl-a is an important pigment for the photosynthesis of phytoplankton (Liu et al., 2013; Li et al., 2015; Lu et al., 2015) and an important medium for absorbing and transmitting light energy. In environmental science, the concentration of chl-a in phytoplankton is used to understand algal biomass (Eisner et al., 2016; Tebbs et al., 2013; Bowes et al., 2012; Wainger et al., 2016) and the primary productivity (Lee et al., 2015; Mantyla et al., 2008; Bott et al., 2006; Morin et al., 1999) of a water body. Chl-a is used to evaluate the nutritional status (Qin et al., 2014; Naeher et al., 2016; Bell et al., 2014; Terauchi et al., 2014) of the water environment. The traditional chl-a detecting method is breaking the algal cell wall by grinding, repeatedly thawing or using microwave methods, and the total chl-a concentration is then detected by spectrophotometry (Pyo et al., 2016) without distinguishing the different algae. According to the difference of fluorescence characteristics of algae, the chl-a concentration of cyanobacteria, chlorophyta and bacillariophyta can be detected by PAM (pulse-amplitude modulation) chlorophyll fluorometer (Jakob et al., 2005; Beecraft et al., 2017; Ruth et al., 2010), which can reflect the algal biomass and provide strong technical support for studying the community structure of algae.

Reservoir is a typical non-stable water body that is influenced by nature and humans, and its hydrodynamic and ecological characteristics are distinct from those of a natural lake (Teeter et al., 2001). Tiegang Reservoir is the largest water supply reservoir in Shenzhen. Shenzhen has promoted water quality in recent years to improve the water pollution situation of the reservoir, but the total nitrogen (TN) level is still seriously above the standard, and the water quality is poor (grade V) (Zhu et al., 2018; Qin et al., 2014). To date, few studies on Tiegang Reservoirs are available, and most of them are focused on water quality, while studies of the algae community structure and seasonal changing pattern are lacking. Our research group carried out continuous monitoring of the chl-a concentration of cyanobacteria, chlorophyta and bacillariophyta and their main environmental factors from April 2013 to June 2014. The temporal and spatial distribution characteristics and evolution of chl-a in algae were analyzed, the high risk areas and periods of algal blooms were identified, and the relationship between environmental factors and algae was studied. This study provides technical support to explore the mechanism of algal blooms, to ensure the safety of drinking water and to improve the ecological civilization of water.

\section{Materials and methods}

\section{The layout of the study area and sampling sites}

There were a total of 10 sampling sites in Tiegang Reservoir (Fig. 1): the No. 1 site is near the inlet of Xili Reservoir, No. 2 is near the intake point of the water plant, No. 3 and No. 4 are in the running water area in the middle east reservoir (where water flow 
velocity is fast), No. 5 and No. 6 are in the dead water area (where water flow velocity is slow), No. 7 is near the water intake point of Shiyan Reservoir, No. 8 is in the running water area in the western reservoir, No. 9 is near the Jiuwei River, and No. 10 is near the Liaokeng River. For each sampling site, the samples were collected within 3 layers from top to bottom; the surface layer is the water layer approximately $10 \mathrm{~cm}$ below the surface, the transparent layer is the water layer corresponding to the depth of the transparency measurement, and the bottom layer is the water layer approximately 10 $\mathrm{cm}$ above the sediment.
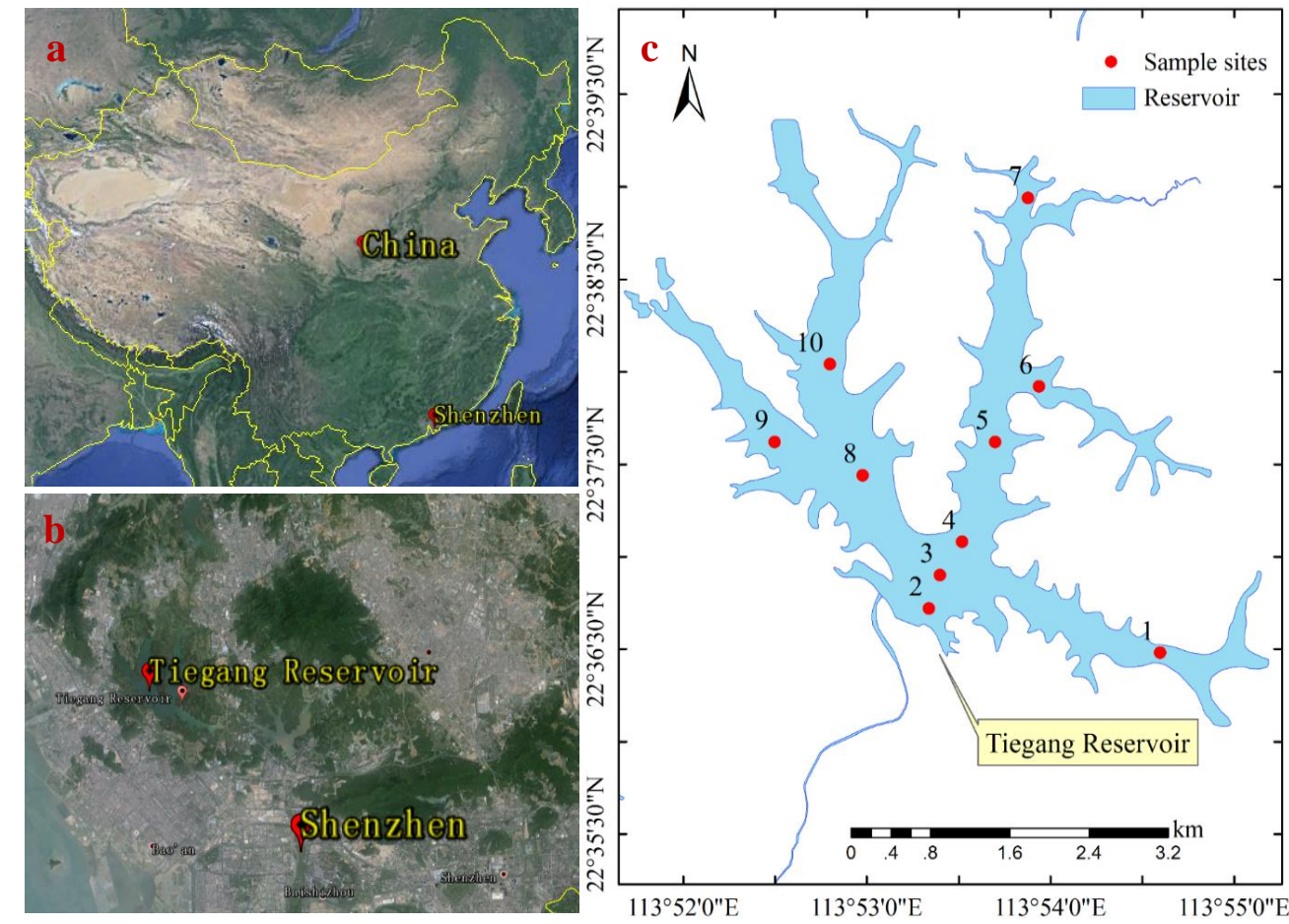

Figure 1. The sampling sites at Tiegang Reservoir

\section{Sampling and analysis}

The samples were collected using a ZPY-1 water collector and stored separately. The water samples were transferred to the laboratory within $2 \mathrm{~h}$ after collected and they were preservated at $4{ }^{\circ} \mathrm{C}$. The chemiluminescence detection of the permanganate index $\left(\mathrm{COD}_{\mathrm{Mn}}\right)$ and determination of $\rho($ Chla), total organic carbon (TOC), total nitrogen (TN), total phosphorus (TP), ammonia nitrogen $\left(\mathrm{NH}_{4}{ }^{+}-\mathrm{N}\right)$, nitrate nitrogen $\left(\mathrm{NO}_{3}{ }^{-} \mathrm{N}\right)$, iron $(\mathrm{Fe})$ and silicate were carried out within two days. Chl-a was measured by using a modulated fluorometer (WALZ Phyto-PAM, Germany) that was periodically calibrated by acetone extraction spectrophotometry. The depth of the water, WT, pH, DO and turbidity were measured in-site using a multi-parameter water quality analyzer (YSI 6600V2, USA). The transparency (SD) was measured in-site using a secchi disk. COD was measured by the acidic potassium permanganate method; TP was determined by ammonium molybdate spectrophotometry (Shimadzu UV-2700 Ultraviolet-Visible Spectrophotometer, Japan); silicate was determined by silicon molybdenum blue spectrophotometry (Shimadzu UV-2700 Ultraviolet-Visible Spectrophotometer, Japan); TN, $\mathrm{NH}_{4}{ }^{+}-\mathrm{N}$ and $\mathrm{NO}_{3}{ }^{-}-\mathrm{N}$ were analyzed by a flow analyzer (AMS-Alliance-Futura, 
French); and TOC was determined using a TOC analyzer (GE-Siever 5310C). The meteorological data, including temperature, air pressure, humidity, rainfall, evapoproportion $\mathrm{n}$ and sunshine hours, were provided by the Shenzhen National Climate Observatory. Three parallel samples were measured for each monitoring sample, and then the average value was taken as the final result.

\section{Climatic periods}

According to the weather characteristics, sampling time was divided into five periods. Pre-rainy period (PRP) was from April to June 2013 and 2014. Latter rainy period (LRP) was from July to September 2013. High temperature and rain free period (HTRFP) was from October to November 2013. Winter drought period (WDP) was from December 2013 to February 2014. Temperature jump period (TJP) was March 2013.

\section{Data processing}

The bivariate relationship between $\rho(\mathrm{Chla})$ and the environmental factors was analyzed by Pearson correlation analysis on SPSS20. *Values in bold are different from 0 with a significance level alpha $=0.05$. **Values in bold are different from 0 with a significance level alpha $=0.01$. Time and space factors on environment factor and $\rho$ (Chla) was analyzed by one-way ANOVA and two-way ANOVA that performed with SPSS20. The comprehensive correlation between the $\rho$ (Chla) of the algae and the environmental factors was carried out using canonical correspondence analysis (CCA) on XLSTAT2010. The distribution chart of algal chl-a was generated on ArcMap10.2 by the Kriging interpolation method based on the mean of the $\rho$ (TChla) of several months at each sampling site in the corresponding climatic period. Other graphics were prepared via using Origin9.0.

\section{Results and discussion}

\section{Spatio-temporal evolution pattern of chl-a}

\section{Spatio-temporal evolution pattern of total chl-a}

Figure 2 shows the seasonal changing pattern of $\rho$ (TChla) in Tiegang Reservoir. The highest $\rho$ (TChla) of Tiegang Reservoir in the sampling period was $145.06 \mu \mathrm{g} \mathrm{L}^{-1}$, which appeared on the surface layer of the No. 9 sampling site on June 17, 2013. The peak period of chlorophyll a in Taihu Lake of China is from July 1 to 10 every year (Liu et al., 2019). Compared with Taihu Lake, the peak period of algae in Tiegang Reservoir is 2-3 weeks earlier. This is mainly because Tiegang Reservoir is located in the subtropical zone and its temperature is higher than that in the Taihu Lake Basin. The lowest $\rho$ (TChla) was $4.72 \mu \mathrm{g} \mathrm{L}^{-1}$, which appeared on the bottom layer of the No. 1

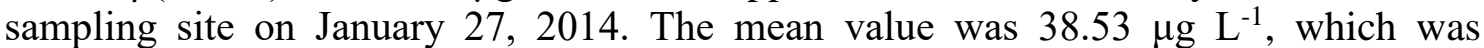
significantly higher than the value of $16.84 \mu \mathrm{g} \mathrm{L}^{-1}$ for the upstream reservoir - Xili Reservoir and lower than the value of $52.03 \mu \mathrm{g} \mathrm{\textrm {L } ^ { - 1 }}$ for the downstream reservoir Shiyan Reservoir in the same period. These results indicate that the quality of the water from the Dongjiang River was significantly deteriorated after storage and transfer in the cascade reservoirs, and the water body had evolved from an oligotrophic state to a mesotrophic state. 


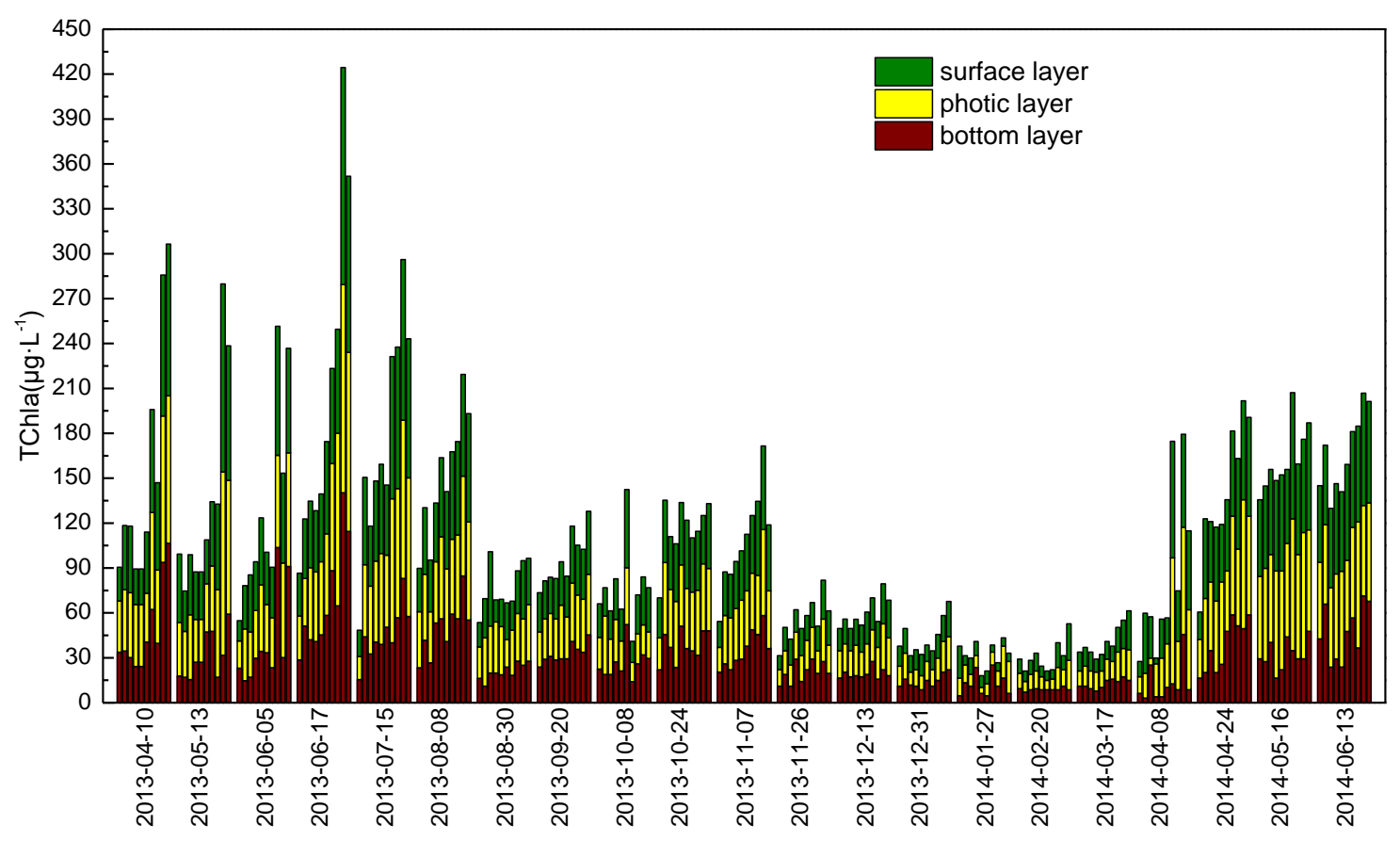

Figure 2. Annual trend in total chl-a concentration. There are 10 columns every month and each column from left to right represents sampling sites 1 to sampling sites 10

The temporal heterogeneity of chl-a in the algae of Tiegang Reservoir was evident: the algae began anabiosis in the temperature rising period in March 2013. The $\rho$ (TChla) increased rapidly in April 2013 and reached $67.43 \mu \mathrm{g} \mathrm{L}^{-1}$ on June 17, 2013, which was the highest level for the year. From July to August 2013, the $\rho$ (TChla) remained high, began to decline in September and remained at a medium concentration level in November, with an average value of $\rho$ (TChla) in this period of $33.29 \mu \mathrm{g} \mathrm{L}^{-1}$. From December 2013 to February 2014, the $\rho$ (TChla) was at the lowest level of the whole year due to the low temperature, and the average value of $\rho$ (TChla) in this period was $14.26 \mu \mathrm{g} \mathrm{L}^{-1}$. From March to April 2014, the $\rho$ (TChla) increased sharply due to the increased temperature and runoff pollution from the average of $14.4 \mu \mathrm{g} \mathrm{L}^{-1}$ on March 17 to $35.10 \mu \mathrm{g} \mathrm{L}^{-1}$ on April 8th. From May to June 2014, the reservoir again entered the high algae laden period.

The spatial heterogeneity of chl-a in the algae during the rainy season was obvious, especially from April 10 to August 8, 2013. The $\rho$ (TChla) of the No. 9 and No. 10 sampling sites was approximately 1.5-2 times that of other sampling sites because these sites were close to the Jiuwei River and Liaokeng River and were affected by river basin pollution. From August 30 to September 20, 2013, at the end of the rainy season, the spatial heterogeneity of $\rho$ (TChla) decreased because the pollutants in the watershed were rinsed by the heavy rainfall from April to July 2013, resulting in a significant decrease in the intensity of pollution. In August and September, although there was still heavy rainfall, the concentration of pollutants from the runoff was significantly reduced, and the concentration of algae in the inlet area from the rivers to the reservoir was also reduced due to dilution by the runoff. The spatial heterogeneity of $\rho$ (TChla) at each sampling site in the periods of high temperature and rain free, winter drought and temperature jump was not clear. On April 8, 2014, with the arrival of the new rainy season, the $\rho$ (TChla) of the No. 9 and No. 10 sampling sites in the northwest of the 
reservoir was significantly increased, and the spatial heterogeneity of the $\rho$ (TChla) in the reservoir was again observed.

The chlorophyll-a of algae has a certain spatial heterogeneity in the vertical direction. The distribution pattern of $\rho$ (TChla) is the transparent layer $>$ the surface layer $>$ the bottom layer. The deeper the water, the more obvious this pattern became. At a water depth of 3-5 m, the algae showed a distribution pattern of the transparent layer $>$ the surface layer $>$ the bottom layer. At a water depth of 5-8 m, the $\rho$ (TChla) of the bottom layer decreased rapidly, and its differences between the surface layer or transparent layer became enlarged. At a water depth of 8-15 m, the mean $\rho$ (TChla) of the bottom layer was only approximately $3 / 5$ that of the transparent layer. The spatial heterogeneity of chl-a in the vertical direction in a natural water body is mainly caused by the stratification of light and the water temperature (Nishijima et al., 2016). The deeper the water body, the greater the difference of the water temperature and light between the different water layers is and the more obvious the difference of $\rho$ (TChla) should be. The $\rho$ (TChla) of Tiegang Reservoir did not show a large difference between the bottom layer and the surface layer as in natural deep lake reservoirs, mainly because Tiegang Reservoir is a typical unstable water body affected by artificial water, with fast water flow and frequent exchange. This was especially true for the sampling sites at the intake points of the water plant and the downstream reservoir, which were 3-6 m under the water surface, thus promoting water exchange in the vertical direction and reducing the spatial heterogeneity of the algae in the vertical direction.

\section{Spatio-temporal evolution pattern of chl-a and community structure of phytoplankton}

Figure 3 shows the seasonal changing pattern of the chl-a concentration of cyanobacteria, chlorophyta and bacillariophyta in the surface layer, the transparent layer and the bottom layer of the water body. During the monitoring period, the mean value of the $\rho$ (Chla) of cyanobacteria was $22.74 \mu \mathrm{g} \mathrm{L}^{-1}$; the highest value was $98.95 \mu \mathrm{g} \mathrm{L}^{-1}$ in the surface layer of the No. 9 sampling site on June 17, 2013, and the lowest value was $1.57 \mu \mathrm{g} \mathrm{L}^{-1}$ in the bottom layer of the No. 1 sampling site on December 31, 2013. The highest monthly average was $43.98 \mu \mathrm{g} \mathrm{L}^{-1}$ in July 2013, and the lowest monthly average was $4.43 \mu \mathrm{g} \mathrm{L}^{-1}$ in January 2014. The mean value of the $\rho$ (Chla) of bacillariophyta was $11.53 \mu \mathrm{g} \mathrm{L}^{-1}$; the highest value was $49.27 \mu \mathrm{g} \mathrm{L}^{-1}$ in the transparent layer of the No. 10 sampling site on April 10, 2013, and the lowest value was $3.15 \mu \mathrm{g} \mathrm{L}^{-1}$ in the bottom layer of the No. 1 sampling site on January 27, 2014. The highest monthly average was 22.63 $\mu \mathrm{g} \mathrm{L}^{-1}$ in April 2013, and the lowest monthly average was $4.18 \mu \mathrm{g} \mathrm{L}^{-1}$ in January 2014. The mean value of the $\rho$ (Chla) of chlorophyta was $4.54 \mu \mathrm{g} \mathrm{L}^{-1}$; the highest value was $18.66 \mu \mathrm{g} \mathrm{L}^{-1}$ in the surface layer of the No. 9 sampling site on June 17, 2013, and the lowest value was $0.18 \mu \mathrm{g} \mathrm{L}^{-1}$ in the bottom layer of the No. 2 sampling site on January 27, 2014. The highest monthly average was $9.24 \mu \mathrm{g} \mathrm{L}^{-1}$ in June 2013, and the lowest monthly average was $1.18 \mu \mathrm{g} \mathrm{L}^{-1}$ in February 2014.

The changing pattern of the $\rho($ Chla $)$ of cyanobacteria was essentially the same as that of $\rho$ (TChla) described in the previous section: rising in the early rainy season in 2013, reaching the highest level in June-August, decreasing to a lower level in SeptemberNovember, reaching the lowest level in December 2013-March 2014 and rapidly rising in early April 2014 to reach a high in June 2014. Compared with the same period of the previous year, the $\rho(\mathrm{Chla})$ of cyanobacteria was increased by $30 \%-50 \%$ from May to June in 2014, indicating that the diversity of algae in the reservoir decreased, and the risk of a cyanobacteria bloom further intensified. The $\rho($ Chla $)$ of bacillariophyta reached 
a maximum at March-April each year, which was slightly decreased in May-July and remained low from August to early October. From late October to early December, due to the sharp decrease of cyanobacteria, the interspecific competition was weakened; thus, the $\rho(\mathrm{Chla})$ of bacillariophyta rose again. In late December to February, due to the cold weather, the $\rho($ Chla $)$ of bacillariophyta was reduced again and was at the lowest level of the year. The $\rho$ (Chla) of chlorophyta was relatively low, showing the overall characteristic of being high in the summer and autumn and low in the winter and spring.

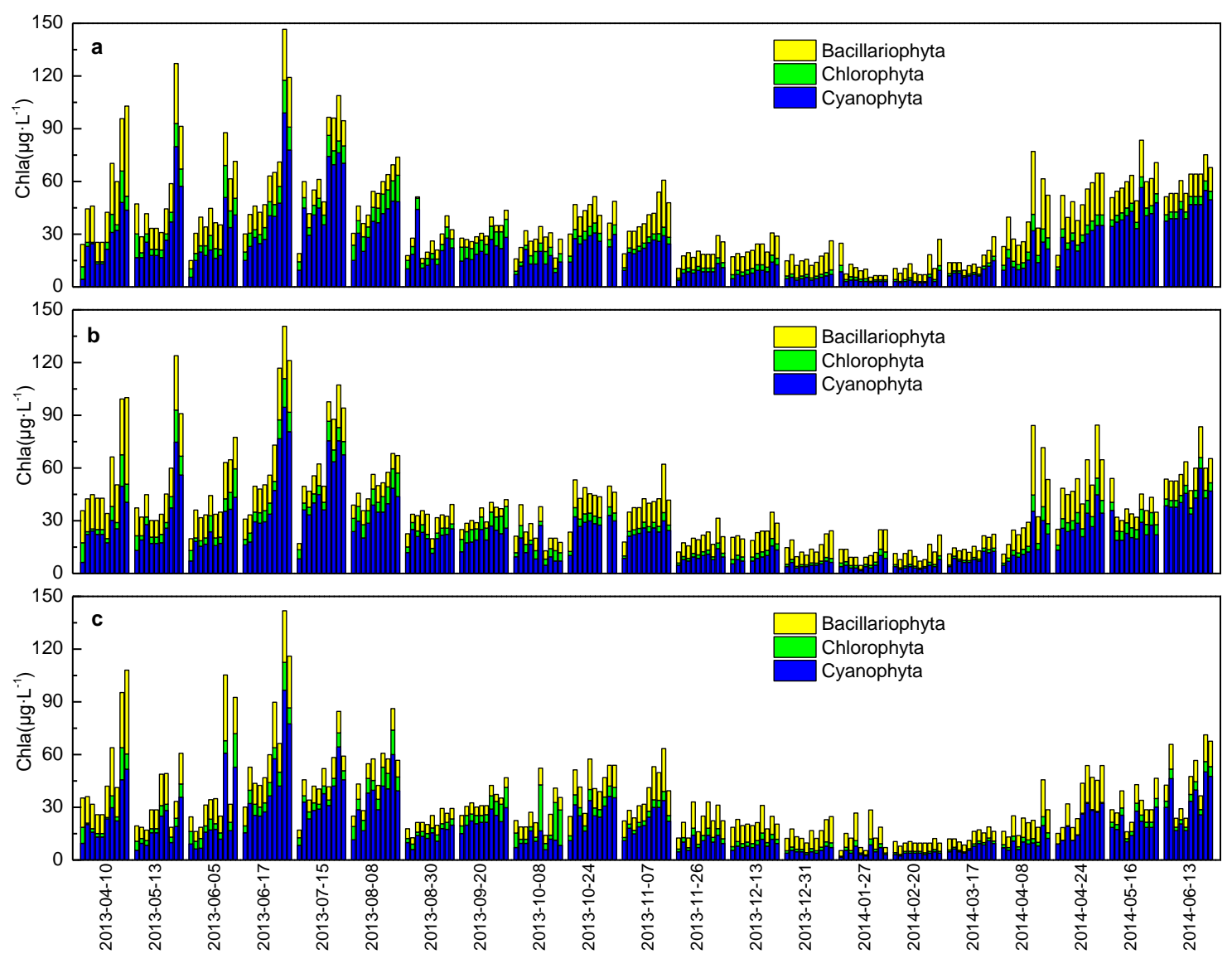

Figure 3. Annual trend in chl-a concentration of cyonophyta, chlorophyt and bacillariophyta: a surface layer; $\boldsymbol{b}$ photic layer; $\boldsymbol{c}$ bottom layer. There are 10 columns every month and each column from left to right represents sampling sites 1 to 10

Figure 4 shows the changing pattern of the algae population structure. The dominance of cyanobacteria in Tiegang Reservoir was apparent, accounting for $27.21 \%-72.58 \%$, with an average of $54.49 \%$. Bacillariophyta dominated in the winter and spring, accounting for $16.27 \%-61.82 \%$, with an average of $34.17 \%$. Chlorophyta was always at a low level, accounting for $7.21 \%-17.03 \%$ for the entire monitoring period, with an average of $11.38 \%$. From April 2013 to July 2013, the proportion of cyanobacteria gradually increased from $49.28 \%$ to $72.58 \%$ and was maintained at approximately 65\% until October. After December 2013, cyanobacteria rapidly decreased until the loss of dominance in December and finally reached the minimum in February 2014. In March 2014, cyanobacteria began to recover and reached $53.83 \%$ in late April to become dominant again; then, the proportion quickly rose to $71.28 \%$ in 
June. The changing trend of bacillariophyta was the opposite of that of cyanobacteria, which decreased from $43.41 \%$ in April 2013 to $16.27 \%$ in July 2013 and remained low in August-September. In October, the proportion of bacillariophyta rebounded rapidly to $46.99 \%$ at the end of December, becoming the dominant algae; this dominance was maintained until the beginning of April 2014 and reached a peak in February-March 2014. This was followed by a rapid decline under the impact of cyanobacteria recovery, falling to $21.47 \%$ in June 2014. The proportion of chlorophyta was low throughout the year, showing no obvious changing pattern in the proportion throughout the year. Compared with the same period of the previous year, the proportion of cyanobacteria in Tiegang Reservoir was increased in May-June 2014, and the proportions of bacillariophyta and chlorophyta decreased with the decreased diversity of algae. The algal population structure is a measure of the ecological diversity and stability of the water body (Pinckney et al., 2017; Tachibana et al., 2017; Tian et al., 2017). Tiegang Reservoir was dominated by cyanobacteria; the algal structure was relatively simple, with poor diversity, and the risk of a cyanobacteria bloom was rising.

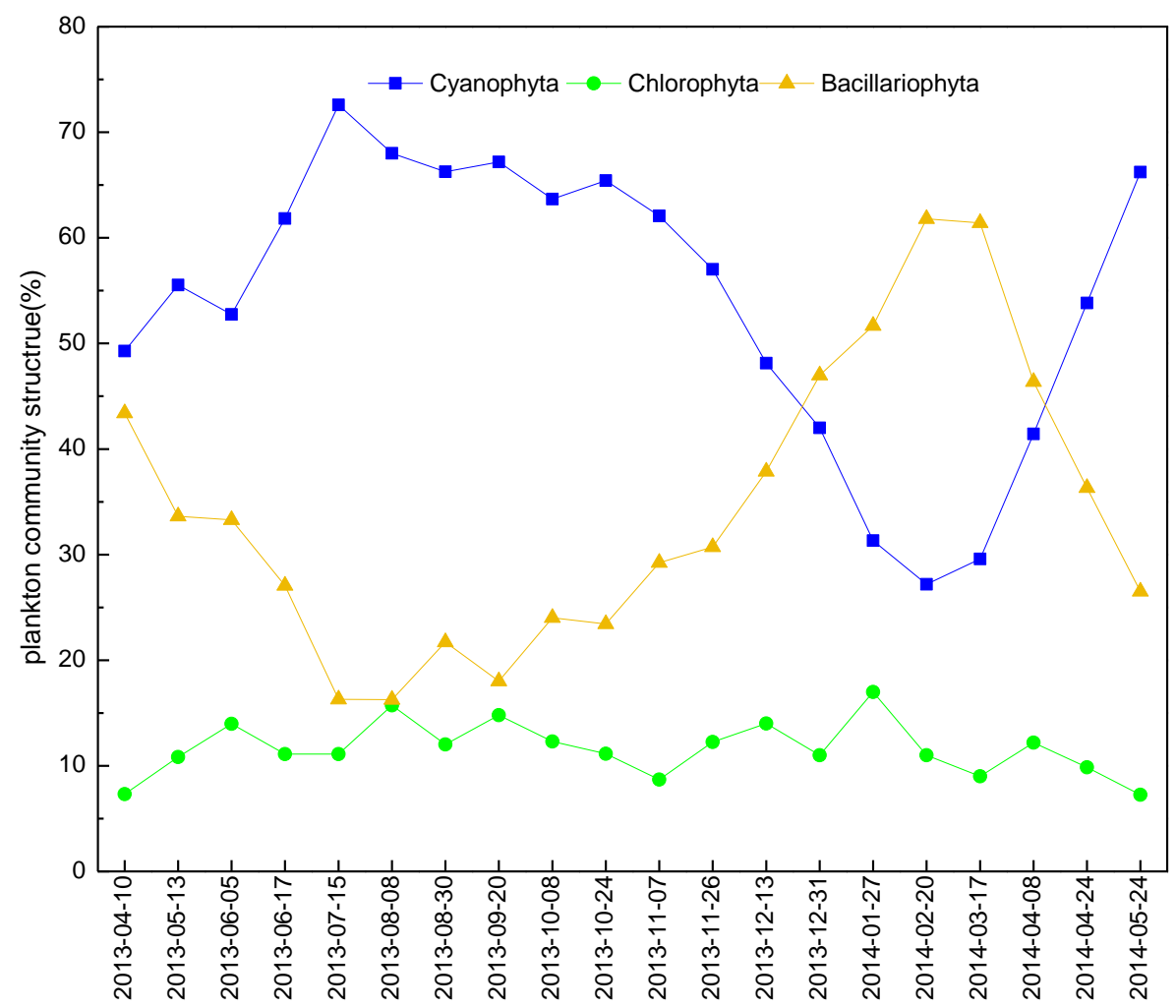

Figure 4. Community structure of phytoplankton in Tiegang Reservoir

\section{Identification of the high risk area of an algal bloom}

Tiegang Reservoir has a large capacity and a high spatial heterogeneity of $\rho(\mathrm{Chla})$, showing the overall characteristic of gradual increases from the southeast to the northwest of the reservoir area (Fig. 5). From the perspective of time, the northwest and northeastern reservoir areas in the early rainy season and the northwest reservoir area in the late rainy season were at high risk of a cyanobacteria bloom, and the reservoir areas near the No. 9 and No. 10 sampling sites had a mild algal bloom in June-July 2013. 
There is a moderate risk of cyanobacteria bloom in the northeastern reservoir area in the late rainy season and the northwest reservoir area in the high temperature and dry period. The winter drought period and temperature jump period showed no risk of cyanobacteria bloom.

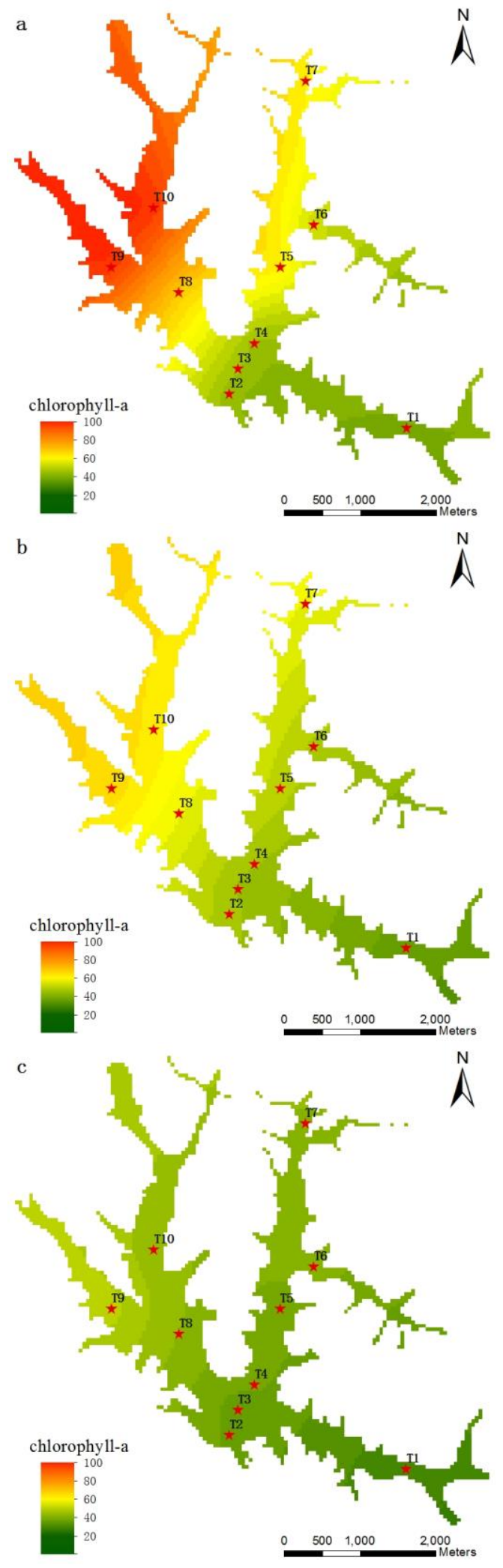




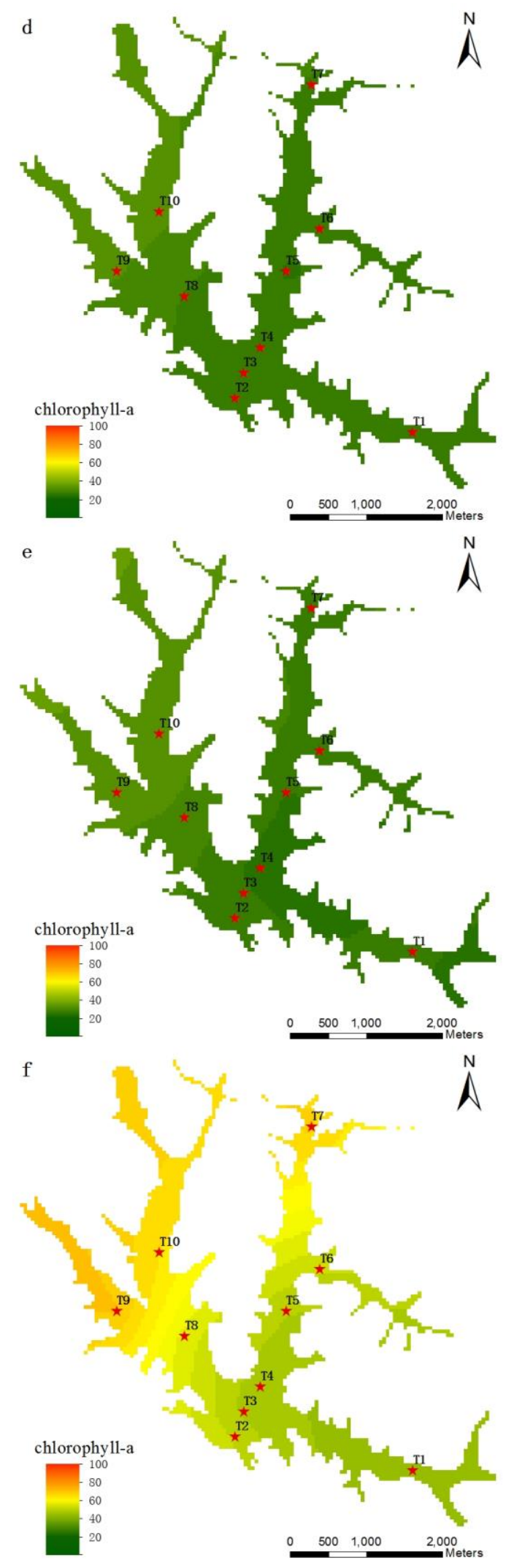

Figure 5. Chl-a chart in different climatic period at Tiegang Reservior. a 2013 pre-rainy period; $\boldsymbol{b} 2013$ latter rainy period; $\boldsymbol{c} 2013$ high temperature and rain free period; $\boldsymbol{d} 2013$ winter drought period; $\boldsymbol{e} 2014$ temperature rising period; $\boldsymbol{f} 2014$ pre-rainy period 
From the perspective of space, the No. 1 sampling site was at the inlet of Tiegang Reservoir from the Xili Reservoir, whose $\rho$ (TChla) was 4.72-55.01 $\mu \mathrm{g} \mathrm{L}^{-1}$, with an average of $21.13 \mu \mathrm{g} \mathrm{\textrm {L } ^ { - 1 }}$. The water quality was relatively good, and the algae concentration was low. The No. 2 sampling site was close to the water intake point from Tiegang Reservoir for the water plant. Because of the daily water supply to the water plant, the water exchange was most frequent in the No. 2 sampling site; therefore, the growth of algae was inhibited, with a mean $\rho$ (TChla) value of $25.14 \mu \mathrm{g} \mathrm{L}^{-1}$, showing good water quality. The No. 1 and No. 2 sampling sites were essentially free of algal blooms. The No. 3 and No. 4 sampling sites were located in the center of the reservoir, with good hydrodynamic conditions, whose mean values of $\rho$ (TChla) were $28.50 \mu \mathrm{g} \mathrm{L}^{-1}$ and $28.16 \mu \mathrm{g} \mathrm{L}^{-1}$, respectively, showing a relatively low risk of algal bloom. The No. 5 and No. 6 sampling sites were located in the dead water area, whose mean values of $\rho$ (TChla) were $32.63 \mu \mathrm{g} \mathrm{L}^{-1}$ and $31.83 \mu \mathrm{g} \mathrm{L} \mathrm{L}^{-1}$, respectively, showing a moderate risk of algae bloom in the rainy season. This was especially true for the No. 5 sampling site in June 2013, with a $\rho\left(\right.$ Chla) of 104.88-122.43 $\mu \mathrm{g} \mathrm{L}^{-1}$, showing a sign of mild algal bloom. The No. 7 sampling site was at the inlet from Tiegang Reservoir to the Shiyan Reservoir, whose $\rho$ (TChla) was 4.07-96.17 $\mu \mathrm{g} \mathrm{L} \mathrm{L}^{-1}$, with a mean value of $69.01 \mu \mathrm{g} \mathrm{L}^{-1}$, showing a moderate risk of algal bloom in the rainy season. The No. 9 and No. 10 sampling sites were close to the entry from the Jiuwei River and Liaokeng River, whose mean values of $\rho$ (TChla) were $53.50 \mu \mathrm{g} \mathrm{L}^{-1}$ and $67.01 \mu \mathrm{g} \mathrm{L}^{-1}$, respectively. The maximum values of $\rho$ (TChla) were $145.06 \mu \mathrm{g} \mathrm{\textrm {L } ^ { - 1 }}$ and $119.62 \mu \mathrm{g} \mathrm{\textrm {L } ^ { - 1 }}$ in June 2013, respectively. Except for the winter dry storage period and the temperature rising period, the No. 9 and No. 10 sampling sites were at moderate or high risk of algal bloom in all other months, and the water supply safety was threatened, which needs to be addressed. The No. 8 sampling site was located at the intersection of the No. 9 and No. 10 sampling site waters, whose average annual $\rho$ (Chla) was $39.42 \mu \mathrm{g} \mathrm{L}^{-1}$, also showing a certain risk of algal bloom in the rainy season. Overall, most areas of Tiegang Reservoir are already in a mesotrophic state, and some areas are in the transition to a eutrophic state.

\section{Multivariate analysis of chl-a and environmental factors}

\section{Pearson correlation analysis of chl-a and water quality factors}

Table 1 shows the relationship between chl-a and water quality factors in the flood and drought seasons. The main correlation factors of cyonophyta, chlorophyt and bacillariophyta in different periods were different. The main correlation factors of cyanobacteria in descending order of the absolute value of the correlation coefficient for the rainy season were $\mathrm{WT}>$ transparency $>$ turbidity $>\mathrm{N}: \mathrm{P}>\mathrm{TP}>$ silicate $>\mathrm{TOC}$, in which transparency, N:P and silicate were negatively correlated. The main correlation factors of cyanobacteria in descending order of the absolute value of the correlation coefficient for the drought season were $\mathrm{TOC}>\mathrm{WT}>\mathrm{NO}_{3}{ }^{-} \mathrm{N}>\mathrm{TN}>\mathrm{Fe}>\mathrm{N}: \mathrm{P}$, in which the $\mathrm{NO}_{3}{ }^{-} \mathrm{N}, \mathrm{TN}, \mathrm{Fe}$ and $\mathrm{N}: \mathrm{P}$ were negatively correlated. The main correlation factors of bacillariophyta in descending order of the absolute value of the correlation coefficient for the rainy season were $\mathrm{WT}>\mathrm{TP}>\mathrm{TN}>\mathrm{TOC}>\mathrm{NO}_{3}{ }^{-} \mathrm{N}$, in which the WT and TOC were negatively correlated. The main correlation factors of bacillariophyta in descending order of the absolute value of the correlation coefficient for the drought season were silicate $>\mathrm{N}: \mathrm{P}>\mathrm{TN}>$ transparency $>\mathrm{NO}_{3}{ }^{-} \mathrm{N}>\mathrm{Fe}$, in which $\mathrm{N}: \mathrm{P}, \mathrm{TN}$, transparency, $\mathrm{NO}_{3}^{-}-\mathrm{N}$ and $\mathrm{Fe}$ were negatively correlated. The main 
correlation factors of chlorophyta in descending order of the absolute value of the correlation coefficient for the rainy season were $\mathrm{COD}>$ transparency $>\mathrm{TOC}>\mathrm{NO}_{3}^{-}-$ $\mathrm{N}>\mathrm{DO}>\mathrm{WT}$, in which transparency and $\mathrm{NO}_{3}{ }^{-} \mathrm{N}$ were negatively correlated. The main correlation factors of chlorophyta in descending order of the absolute value of the correlation coefficient for the drought season were TOC $>$ WT $>$ TP $>\mathrm{N}: \mathrm{P}>$ $\mathrm{pH}>\mathrm{COD}$, in which $\mathrm{N}: \mathrm{P}$ was negatively correlated. In general, the correlations between the three algae and the water quality factors in the drought season were significantly higher than those in the rainy season. This likely occurs because the algae concentration was significantly decreased by the dilution effect of the heavy rainfall (Bernal-Brooks et al., 2016) in a short time during the rainy season, leading to strong fluctuations in the chl-a concentration; therefore, the correlation with water quality factors was reduced.

Table 1. Pearson correlation coefficients between chl-a and water quality factors

\begin{tabular}{|c|c|c|c|c|c|c|c|c|c|c|c|c|c|c|}
\hline Period & Phytoplankton & DO & pH & WT & SD & Turbidity & COD & TOC & Silicate & $\mathrm{NO}_{3}{ }^{-}-\mathrm{N}$ & TN & TP & $\mathbf{N}: \mathbf{P}$ & $\mathrm{Fe}$ \\
\hline \multirow{4}{*}{$\begin{array}{l}\text { Rainy } \\
\text { season }\end{array}$} & Cyanophyta & 0.047 & -0.008 & $0.418^{* *}$ & $-0.393^{* *}$ & $0.360^{* *}$ & 0.152 & $0^{0.233}{ }^{*}$ & $-0.261^{*}$ & -0.042 & 0.132 & $0.284^{* *}$ & $-0.310^{* *}$ & -0.105 \\
\hline & Bacillariophyta & -0.176 & -0.080 & $-0.562^{* *}$ & 0.127 & 0.022 & -0.183 & $-0.403^{* *}$ & -0.195 & $0.354^{* *}$ & $\mathbf{0 . 4 5 4}^{* *}$ & $0.475^{* *}$ & $-0.238^{*}$ & -0.135 \\
\hline & Chlorophyta & $\operatorname{0.308}^{* *}$ & $0.213^{*}$ & $0.273^{* *}$ & $-0.445^{* *}$ & 0.142 & $0.5366^{* *}$ & $\mathbf{0 . 3 3 9}^{* *}$ & $0.253^{*}$ & $-0.322^{* *}$ & 0.002 & -0.075 & -0.007 & 0.023 \\
\hline & Total Algae & 0.013 & -0.004 & -0.028 & $-0.283^{* *}$ & $0.271^{*}$ & 0.114 & 0.062 & -0.209 & 0.052 & $0.286^{* *}$ & $0.350^{* *}$ & $-0.294^{* *}$ & -0.115 \\
\hline \multirow{4}{*}{$\begin{array}{l}\text { Drought } \\
\text { season }\end{array}$} & & 0.124 & $0.398^{* *}$ & $0.651^{* *}$ & -0.251 & & 0.133 & $0.778^{* *}$ & $0.425^{* *}$ & $-0.618^{* *}$ & $-0.616^{* *}$ & $0.274^{* *}$ & $-0.442^{* *}$ & $-0.513^{* *}$ \\
\hline & Bacillariophyta & $0.224^{* *}$ & $0.309^{* *}$ & $0.268^{* *}$ & $-0.400^{* *}$ & 0.085 & 0.049 & $0.434^{* *}$ & $0.478^{* *}$ & $-0.396^{* *}$ & $-0.460^{* *}$ & $0.263^{* *}$ & $-0.461^{* *}$ & $-0.369^{* *}$ \\
\hline & Chlorophyta & 0.178 & $0.502^{* *}$ & $0.695^{* *}$ & $-0.474^{* *}$ & -0.013 & $0.475^{* *}$ & $0.758^{* *}$ & $0.465^{* *}$ & $-\mathbf{0 . 3 9 0} 0^{* *}$ & $-0.414^{* *}$ & $0.601^{* *}$ & $-0.541^{* *}$ & $-0.388^{* *}$ \\
\hline & Total Algae & 0.181 & $0.428^{* *}$ & $0.601^{* *}$ & $-0.361^{* *}$ & -0.015 & 0.160 & $0.750^{* *}$ & $0.501^{* * *}$ & $-0.615^{* *}$ & $-0.613^{* *}$ & $0.343^{* *}$ & $-0.515^{* *}$ & $-0.511^{* *}$ \\
\hline \multirow{4}{*}{$\begin{array}{l}\text { Whole } \\
\text { time }\end{array}$} & & 0.041 & 0.157 & $0.659^{* *}$ & $-0.323^{* *}$ & $0.208^{* *}$ & $0.270^{* *}$ & $0.600^{* *}$ & -0.129 & $-0.215^{* *}$ & 0.134 & 0.161 & -0.187 & $-0.242^{* *}$ \\
\hline & Bacillariophyta & -0.073 & 0.087 & 0.165 & -0.141 & 0.005 & 0.024 & 0.085 & -0.029 & 0.145 & $0.378^{* *}$ & $0.350^{* *}$ & $-0.236^{* *}$ & $-0.226 * *$ \\
\hline & Chlorophyta & 0.196 & $0.266^{* *}$ & $0.663^{* *}$ & $-0.389^{* *}$ & 0.016 & $0.491^{* *}$ & $0.626^{* *}$ & 0.100 & $-0.352^{* *}$ & 0.095 & 0.029 & -0.050 & -0.146 \\
\hline & Total Algae & 0.034 & 0.169 & $0.590^{* *}$ & $-0.315^{* *}$ & 0.176 & $0.259^{* *}$ & $0.521^{* *}$ & -0.083 & -0.154 & $0.213^{* *}$ & $0.215^{* *}$ & $-0.203^{* *}$ & $-0.250^{* *}$ \\
\hline
\end{tabular}

Rainy season was from April to September 2013 and April to July 2014. Drought season was from October 2013 to March 2014. *Significant at the 0.05 level. **Significant at the 0.01 level. DO-dissolved oxygen. WT: water temperature, SD: transparency, COD: chemical oxygen demand, TOC: total organic carbon, TN: total nitrogen, $\mathrm{NO}^{3-}: \mathrm{N}$-nitrate nitrogen, TP: total phosphorus, $\mathrm{N}$ : P-the proportion of TN to TP

In particular, in the rainy season, the WT was positively correlated to cyanobacteria, with a correlation coefficient of 0.418 , and was negatively correlated to bacillariophyta, with a correlation coefficient of -0.562 . It was found that rising temperatures $(1.4-$ $6.8^{\circ} \mathrm{C}$ ) could increase cyanobacteria growth rates and increase cyanobacteria bloom occurrences (Davis et al., 2009; Wu et al., 2014; O Neil et al., 2012). The optimum temperature for microcytic species are $30-33{ }^{\circ} \mathrm{C}$ (Mowe et al., 2017). Fadel et al. (2015) investigated a freshwater reservoir in the Mediterranean and found that when the WT exceeded $25^{\circ} \mathrm{C}$, the cyanobacteria represented by microcystis began to multiply. It was found that the suitable temperature for the growth of bacillariophyta was $10-25^{\circ} \mathrm{C}$ (Mitrovic et al., 2010), and the maximum growth rate occurred at $20^{\circ} \mathrm{C}$, and the growth rate of bacillariophyta was inhibited and the biomass began to decrease when the WT exceeded $25^{\circ} \mathrm{C}$ (Jung et al., 2013). The WT of Tiegang Reservoir was $22.46-32.79{ }^{\circ} \mathrm{C}$ in the rainy season, with an average of $29.44{ }^{\circ} \mathrm{C}$, and reached $28^{\circ} \mathrm{C}$ in May. The higher WT is beneficial to the growth and reproduction of cyanobacteria, and it somehow inhibits the growth of bacillariophyta, which allows the cyanobacteria to gain an advantage over bacillariophyta. Therefore, the WT was positively correlated with cyanobacteria and negatively correlated with bacillariophyta in the rainy season. In the rainy season, the concentration of cyanobacteria was positively correlated with turbidity and negatively correlated with transparency, indicating that the rapid increase of 
cyanobacteria in the rainy season increased the water turbidity while reducing the water transparency and light intensity. The photosynthesis of algae is limited with reduced light intensity in a water body. However, some cyanobacteria have pseudo-vacuoles, which can float up to the surface water layer where the light intensity is higher, and they will subsequently not be inhibited by the weakening of light. Bacillariophyta are more widely distributed in the middle layers of water, and the high turbidity and low light intensity of the water body will therefore more significantly affect the growth of bacillariophyta. In the rainy season, TN was significantly correlated with bacillariophyta, and TP showed a certain correlation with both bacillariophyta and cyanobacteria, indicating that nitrogen and phosphorus are the important factors for algae growth. Tiegang Reservoir is a nitrogen-contaminated reservoir, with total nitrogen levels up to $1.64 \mathrm{mg} \mathrm{L}^{-1}$, a surface water quality of grade $\mathrm{V}$, and TP levels as low as $0.024 \mathrm{mg} \mathrm{L}^{-1}$, belonging to the surface water quality of grade II. For algal growth, TN is relatively abundant, and TP is relatively scarce, and phosphorus is a limiting nutrient for algal growth. The $\mathrm{N}$ : $\mathrm{P}$ of Tiegang Reservoir in the rainy season and drought season was 69 and 54, respectively, and the $\mathrm{N}$ : P showed a negative correlation with cyanobacteria and bacillariophyta, indicating that a high $\mathrm{N}$ : $\mathrm{P}$ was not favorable for the growth of algae. This result is consistent with the findings of Smith (1983), who proposed the "N: P law" based on the study of 17 lakes; that is, cyanobacteria blooms can easily outbreak when N: P is lower than 29. The WT in the drought season was still the main influencing factor for all three algae, especially for chlorophyta and cyanobacteria, with correlation coefficients as high as 0.695 and 0.651 , respectively. All three algae in the drought season showed significant negative correlations with water quality factors, including $\mathrm{NO}_{3}{ }^{-} \mathrm{N}, \mathrm{TN}$ and Fe. There were two main reasons for this phenomenon. On the one hand, the $\rho$ (Chla) of algae in the drought season significantly decreased with decreased temperature. On the other hand, water is lacking in the drought season, and the reservoir was operating at low water level; thus, the concentrations of water quality factors, including $\mathrm{NO}_{3}{ }^{-} \mathrm{N}$ and $\mathrm{TN}$ increased slightly. The transparency was negatively correlated with the three algae at each period to varying degrees, indicating that the growth of algae in the reservoir was not conducive to the transparency of the water body. The correlations between DO and the three algae in each period were not obvious because Tiegang Reservoir is a typical artificial water transfer and supply reservoir, with a highly frequent water exchange and a low stability of the water body. The average concentrations of dissolved oxygen in the rainy season and drought season were 8.89 and $9.12 \mathrm{mg} \mathrm{L}^{-1}$, respectively, which are sufficient to meet the needs of algal growth.

\section{Pearson correlation analysis of chl-a with the meteorological and hydrodynamic factors}

Table 2 shows the correlation of chl-a with the meteorological factors and hydrodynamic factors in the flood and drought seasons. On the same day, the collected hydrodynamic factors and meteorological factors should be the same, and the data characteristics were different from those of water quality factors. Therefore, their correlations with the chl-a were analyzed separately. Table 2 shows that there were significant differences in the main correlated factors of different algae in the same period and the same algae at different periods. The main correlated factors of different algae in different periods were different. In the rainy season, the main correlated factors of cyanobacteria in descending order of the absolute value of the correlation coefficient 
were $\quad$ WT $>$ evapoproportion $n>$ pressure $>$ runoff $>$ sunshine hours $>$ hydraulic retention times (HRT). The main correlated factors of bacillariophyta in descending order of the absolute value of the correlation coefficient were temperature $>$ evapoproportion $\mathrm{n}>$ sunshine hours $>$ runoff $>$ HRT $>$ pressure. The main correlated factor of chlorophyta was temperature. In the drought season, the main correlated factors of cyanobacteria in descending order of the absolute value of the correlation coefficient were water evapoproportion $n>$ temperature. The main correlated factors of bacillariophyta in descending order of the absolute value of the correlation coefficient were evapoproportion $\mathrm{n}>$ pressure $>$ temperature. The main correlated factors of chlorophyta in descending order of the absolute value of the correlation coefficient were humidity $>$ evapoproportion $\mathrm{n}>$ pressure. Temperature showed a significant positive correlation with cyanobacteria and a significant negative correlation with bacillariophyta, which was consistent with the effect of WT on cyanobacteria and bacillariophyta. Rainfall is the main driving force of watershed pollution entering the reservoir. The rainwater washed the organic matter and nitrogen/phosphorus nutrient salt deposits from the watershed surface into the reservoir in the form of ground surface runoff (Abell and Hamilton, 2015). The runoff in the early rainy season showed a significant negative correlation with cyanobacteria and a negative correlation with bacillariophyta. The runoff in the late rainy season showed a slight negative correlation with all three algae. This occurs because the proportion of organic matter and nutrient salts in the runoff of the early rainy season were high, which could increase the organic matter and nutrient salts in the reservoir and promote the growth and reproduction of cyanobacteria. The water quality of the runoff in the late rainy season was better, which was mainly due to the increased amount of water in the reservoir, which diluted the organic matter, nutrient salts and algae. In the rainy season, HRT was highly negatively correlated with cyanobacteria, indicating that, in order to inhibit the excessive reproduction of cyanobacteria during the rainy season, the reservoir management department can reduce the water retention time by increasing the water supply and reducing the water level of the reservoir to prevent a cyanobacteria bloom. The pressure was negatively correlated with all three algae to different degrees, but the results do not indicate that the pressure has a significant direct effect on algal growth. This is mainly due to the significant negative correlation between air pressure and air temperature in meteorological regularity. Pearson correlation analysis also showed that the correlation coefficients of air temperature and air pressure in the flood and drought seasons were 0.859 and -0.936 , respectively.

\section{Canonical correspondence analysis (CCA) of chl-a and environmental factors}

Canonical correspondence analysis of the relationship of the water quality, meteorological factors and hydrodynamic factors with algae $\rho($ Chla) in the rainy season and the drought season was carried out to investigate the comprehensive effects of the environmental factors on the growth of algae in the flood and drought seasons (Fig. 6). The arrow in the figure indicates the environmental factor, and the length of the arrow indicates the correlation between the algae and this environmental factor. The angle between the arrow line and the ordination axis indicates the correlation between this environmental factor and the ordination axis, and the smaller the angle is, the closer the correlation is. The quadrant of the arrow indicates the positive or negative correlation between the environmental factor and the ordination axis. In the rainy season, cyanobacteria, chlorophyta and bacillariophyta were located in the fourth, first and 
second quadrants, respectively; in the drought season, cyanobacteria, chlorophyta and bacillariophyta were located in the second, fourth and first quadrants, respectively, indicating that the growth patterns of the three algae were different, and the environmental factors influencing the three algae varied widely. The eigenvalues of F1 and F2 in the rainy season were 0.022 and 0.008 , respectively, and the explanatory rates were $72.61 \%$ and $27.39 \%$, respectively. The eigenvalues of F1 and F2 in the drought season were 0.024 and 0.009 , respectively, and the explanatory rates were $73.10 \%$ and $26.90 \%$, respectively.

Table 2. Pearson correlation coefficients between chl-a and hydrodynamic/meteorological factors

\begin{tabular}{|c|c|c|c|c|c|c|c|c|c|}
\hline Period & Phytoplankton & AT & BP & Humidity & SHD & EC & RV & TR & HRT \\
\hline \multirow{4}{*}{$\begin{array}{l}\text { Rainy } \\
\text { season }\end{array}$} & Cyanophyta & $0.401^{* *}$ & $-0.391^{* *}$ & -0.103 & $0.336^{* *}$ & $0.392^{* *}$ & $0.323^{* *}$ & -0.108 & $-0.258^{*}$ \\
\hline & Bacillariophyta & $-0.484^{* *}$ & $0.327^{* *}$ & 0.189 & $-0.386^{* *}$ & -0.129 & -0.104 & $-0.212^{*}$ & 0.347 \\
\hline & Chlorophyta & 0.108 & -0.064 & -0.049 & 0.069 & -0.096 & -0.018 & 0.039 & -0.095 \\
\hline & Total Alage & 0.047 & -0.157 & -0.009 & 0.099 & 0.205 & 0.122 & -0.143 & -0.064 \\
\hline \multirow{4}{*}{$\begin{array}{l}\text { Drought } \\
\text { season }\end{array}$} & Cyanophyta & $0.564^{* *}$ & $-0.352^{* *}$ & -0.138 & 0.009 & $0.401^{* *}$ & -0.082 & -0.118 & -0.172 \\
\hline & Bacillariophyta & 0.071 & 0.069 & $-0.315^{* *}$ & 0.102 & $0.323^{* *}$ & $-0.233^{*}$ & -0.130 & -0.077 \\
\hline & Chlorophyta & $\mathbf{0 . 5 8 9}^{* *}$ & $-0.387^{* *}$ & $-0.450^{* * *}$ & $0.503^{* *}$ & $0.651^{* *}$ & $-0.299^{* *}$ & $-0.377^{* *}$ & $-0.315^{* *}$ \\
\hline & Total Alage & $0.462^{* *}$ & $-0.251^{*}$ & $-0.255^{*}$ & 0.102 & $0.464^{* *}$ & -0.172 & -0.168 & -0.176 \\
\hline \multirow{4}{*}{$\begin{array}{l}\text { Whole } \\
\text { time }\end{array}$} & Cyanophyta & $0.689^{* *}$ & $-0.723^{* *}$ & $0.513^{* *}$ & 0.038 & -0.015 & $0.335^{* *}$ & $0.343^{* *}$ & 0.049 \\
\hline & Bacillariophyta & $0.272^{*}$ & $-0.200^{*}$ & $0.254^{* *}$ & $-0.262^{* *}$ & -0.107 & -0.047 & 0.076 & $0.326^{* *}$ \\
\hline & Chlorophyta & 0.108 & -0.064 & -0.049 & 0.069 & -0.096 & -0.018 & 0.039 & -0.095 \\
\hline & Total Alage & $0.608^{* *}$ & $-0.637^{* *}$ & $0.494^{* *}$ & -0.048 & -0.059 & $0.266^{* *}$ & $0.310^{* *}$ & 0.142 \\
\hline
\end{tabular}

Rainy season was from April to September 2013 and April to July 2014. Drought season was from October 2013 to March 2014. AT: air temperature, BP: barometric pressure, SHD: sunshine duration, EC: evaporation capacity, RV: runoff volume, TR: total rainfall, HRT: hydraulic retention time. *Significant at the 0.05 level. **Significant at the 0.01 level

Figure 6 shows that the environmental factors with the highest correlation degree to algae were the meteorological factors, including the temperature, sunshine hours, pressure and evaporation, indicating that the spatio-temporal distribution and evolution of algae are mainly driven by changes in climate. Panels a and b show that the strongest environmental factor associated with algae in the rainy season and the drought season was WT, followed by air temperature, indicating that temperature is the primary driving factor for algal growth in Tiegang Reservoir. The environmental factors showing the maximum projection on the F1 axes of the two panels were both WT; thus, the F1 axis mainly reflects the change in WT. The number of sunshine hours and the amount of evaporation in both figure $\mathrm{a}$ and figure $\mathrm{b}$ showed positive correlations with algae. Light is the essential condition for the photosynthesis of algae, and the increase of sunshine hours is beneficial to the increase of algal biomass. The amount of evaporation reflects the loss of the reservoir water from liquid to gas; the greater the amount of evaporation is, the more the loss of the reservoir water due to evaporation, resulting in increased algal concentration. Air pressure was negatively correlated with algae and was highly opposite to temperature in figure $\mathrm{a}$ and figure $\mathrm{b}$ since pressure was negatively correlated with temperature in the meteorological regularity; thus, pressure was indirectly negatively correlated with algae, which does not indicate that pressure has a direct causal relationship with algal growth. The hydrodynamic factor HRT reflects the length of residence time of water in the reservoir, which was significantly correlated with algae in both figure a and figure $b$. This negative correlation was especially significant for 
cyanobacteria, indicating that frequent water exchange could inhibit the growth of algae. This finding is consistent with the result of the Pearson correlation analysis. TOC and COD represent the contents of organic matter in the water, whereas TN, ammonia nitrogen, nitrate nitrogen and TP reflect the contents of nutrient salts in the water. The TOC, COD, TN, ammonia nitrogen, nitrate nitrogen and TP were moderately correlated with algal concentration ns in figure a and figure $b$. Silicate was more closely related to algae in the rainy season, and the correlation in the drought season was not obvious. In the drought season, Fe was highly correlated with the F1 axis because Fe is an essential element of algal photosynthesis and metabolism and has an important effect on the biomass and growth rate of algae, especially bacillariophyta (Sugie et al., 2013; Okumura et al., 2013; Russo et al., 2015).
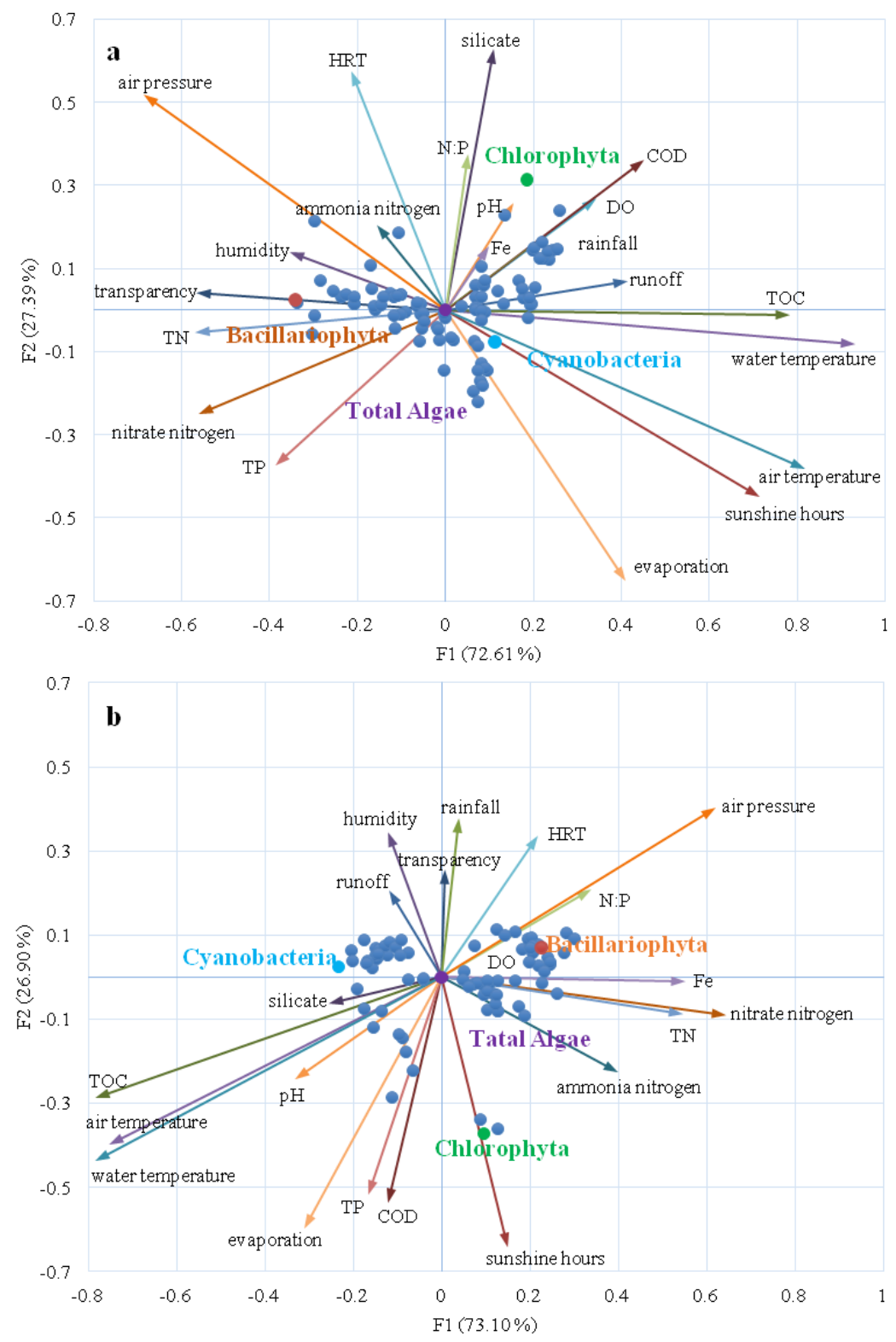

Figure 6. Canonical correspondence analysis of environmental factors and phytoplankton: a rainy period; $\boldsymbol{b}$ drought period. The light blue, green, yellow and purple dots, respectively, represent cyanobacteria, chlorophyta, bacillariophyta and total algae; the dark blue dots indicate the sampling sites; and the arrows indicate the environmental factors 


\section{Influence of environmental factors on the competitiveness of cyanobacteria and Bacillariophyta}

Effects of single environmental factors on the competitiveness of cyanobacteria and Bacillariophyta

Chl-a proportions of cyanobacteria and diatom were used to characterize the competitiveness of cyanobacteria and bacillariophyta, thus describing the potential for growth and eruption. When the chl-a proportion was less than $40 \%$, it meant that the outbreak risk was low. When the chl-a proportion reached $40 \% \sim 60 \%$, it meant that they had slight risk of outbreaks. When the chl-a proportion were more than $60 \%$, it meant that they were at high risk of outbreaks.

Figure 7 shows when WT was lower than $17^{\circ} \mathrm{C}$, the proportion of cyanobacteria was between 30 40\%, and the advantage was not obvious. With the increase of WT, the competitiveness of cyanobacteria increased gradually. When the WT was $21.5^{\circ} \mathrm{C}$, the proportion of cyanobacteria and bacillariophyta were both equal to $48 \%$. The two were equal in competitiveness. There was a high risk of cyanobacteria blooming. When WT reached $28.8^{\circ} \mathrm{C}$, the proportion of cyanobacteria was over $60 \%$, which completely occupied the dominant position. When WT exceeded $30^{\circ} \mathrm{C}$, the cyanobacteria proportion raised to 70\% 80\%, reaching the highest level. The linear fitting formula of cyanobacteria competitiveness and WT was calculated as Equation 1. When WT was below $17.2{ }^{\circ} \mathrm{C}$, the diatom proportion was higher than $60 \%$. Bacillariophyta occupied a dominant position. As the water temperature raised, the diatom proportion decreased gradually. When WT was $21.5^{\circ} \mathrm{C}$, the proportion of cyanobacteria and diatom was both $48 \%$. When WT exceeded $24.3{ }^{\circ} \mathrm{C}$, the diatom proportion fell below $40 \%$, completely losing the dominant position. When WT exceeded $32{ }^{\circ} \mathrm{C}$, the diatom proportion dropped to $10 \sim 15 \%$, reaching the lowest level in the whole year. The linear fitting formula of diatom competitiveness and WT was calcuated as Equation 2.

$$
[\text { Chla-cyanophyta }]=11.94+1.68 \mathrm{WT}, \mathrm{R}^{2}=0.81
$$

$[$ Chla-bacillariophyta $]=107.60-2.76 \mathrm{WT}, \mathrm{R}^{2}=0.49$

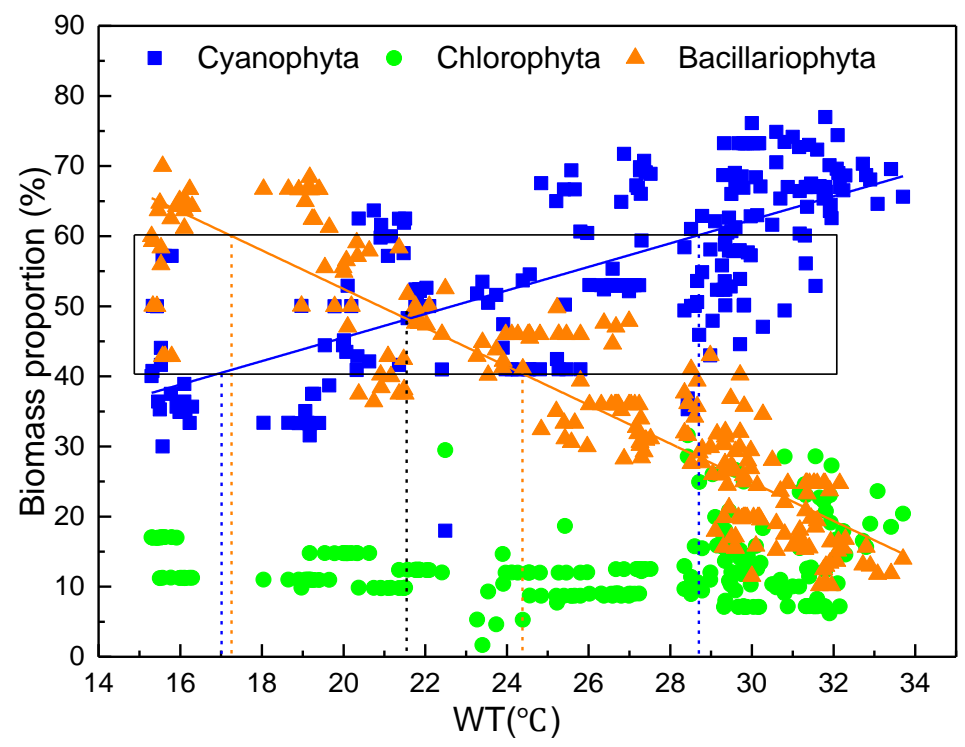

Figure 7. Effects of WT on the competitiveness of cyanobacteria and bacillariophyta 
Figure 8 shows when TOC was below $2.25 \mathrm{mg} / \mathrm{L}$, the proportion of cyanobacteria was between 30 40\%, and its advantage was not obvious. With the increase of TOC, the competitiveness of cyanobacteria increased gradually. When TOC was $2.62 \mathrm{mg} / \mathrm{L}$, the proportion of cyanobacteria and bacillariophyta were both equal to $48 \%$. The two were equal in competitiveness. When TOC reached $4.21 \mathrm{mg} / \mathrm{L}$, the proportion of cyanobacteria was more than $60 \%$, which fully occupied the dominant position. When TOC exceeded $5.0 \mathrm{mg} / \mathrm{L}$, the cyanobacteria proportion raised to $65 \% \sim 75 \%$, reaching the highest level in the year. The linear fitting formula of cyanobacteria competitiveness and TOC was calculated as Equation 3.

When TOC was below $1.70 \mathrm{mg} / \mathrm{L}$, the diatom proportion was higher than $60 \%$. Diatom occupied a dominant position. With the increasing of TOC, the proportion of diatom decreased gradually. When TOC was $2.62 \mathrm{mg} / \mathrm{L}$, the proportion of cyanobacteria and bacillariophyta was both $48 \%$. When TOC exceeded $3.29 \mathrm{mg} / \mathrm{L}$, the diatom proportion fell below $40 \%$, completely losing dominance. When TOC exceeded $4.52 \mathrm{mg} / \mathrm{L}$, the diatom proportion falls to $10 \% \sim 20 \%$, reaching the lowest level of the year. The linear fitting formula of diatom competitiveness and TOC was calculated as Equation 4.

$$
\begin{gathered}
{[\text { Chla-cyanophyta }]=26.11+8.22 \mathrm{TOC}, \mathrm{R}^{2}=0.54} \\
{[\text { Chla-bacillariophyta }]=82.09-12.89 \mathrm{TOC}, \mathrm{R}^{2}=0.69}
\end{gathered}
$$

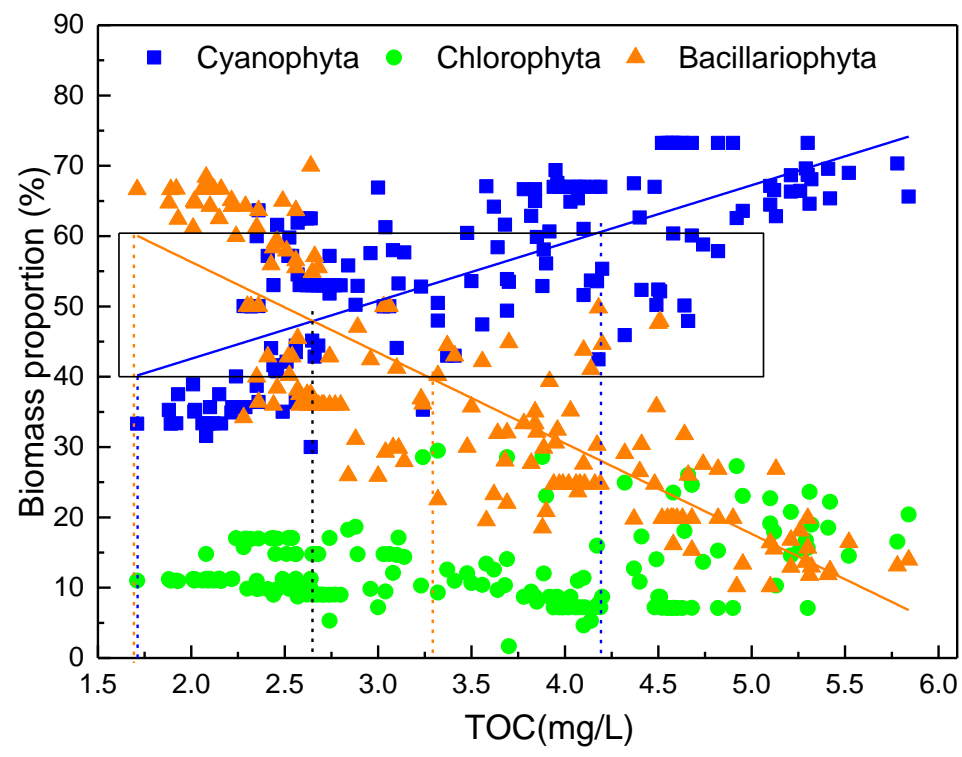

Figure 8. Effects of TOC on the competitiveness of cyanobacteria and bacillariophyta

Figure 9 shows when $\mathrm{NO}_{3}{ }^{-}-\mathrm{N}$ was below $0.82 \mathrm{mg} / \mathrm{L}$, the proportion of cyanobacteria was between $60 \sim 75 \%$, taking full advantage. With the increasing of $\mathrm{NO}_{3}{ }^{-} \mathrm{N}$, the competitiveness of cyanobacteria declined gradually. When $\mathrm{NO}_{3}{ }^{-} \mathrm{N}$ was $1.28 \mathrm{mg} / \mathrm{L}$, the proportion of cyanobacteria and bacillariophyta were both equal to $46 \%$. The two were equal in competitiveness. When $\mathrm{NO}_{3}^{-}-\mathrm{N}$ reached $1.53 \mathrm{mg} / \mathrm{L}$, the proportion of cyanobacteria fell below $40 \%$. Cyanobacteria completely lost dominance. The linear fitting formula of cyanobacteria competition and $\mathrm{NO}_{3}{ }^{-} \mathrm{N}$ was calculated as Equation 5. 
When $\mathrm{NO}_{3}{ }^{-}-\mathrm{N}$ was below $0.82 \mathrm{mg} / \mathrm{L}$, the diatom proportion was below $30 \%$, and the competitiveness was very low. With the increasing of $\mathrm{NO}_{3}^{-}-\mathrm{N}$, the proportion of diatom raised gradually. When $\mathrm{NO}_{3}^{-}-\mathrm{N}$ was $1.28 \mathrm{mg} / \mathrm{L}$, the proportion of cyanobacteria and bacillariophyta was both $48 \%$. When $\mathrm{NO}_{3}{ }^{-}-\mathrm{N}$ exceeded $1.4 \mathrm{mg} / \mathrm{L}$, diatom occupied the dominant position. The linear fitting formula of diatom competition and $\mathrm{NO}_{3}^{-}-\mathrm{N}$ was calculated as Equation 6.

$$
\begin{gathered}
{[\text { Chla-cyanophyta }]=82.97+27.93 \mathrm{NO}_{3}{ }^{-}-\mathrm{N}, \mathrm{R}^{2}=0.28} \\
{[\text { Chla-bacillariophyta }]=-2.59-39.04 \mathrm{NO}_{3}{ }^{-}-\mathrm{N}, \mathrm{R}^{2}=0.30}
\end{gathered}
$$

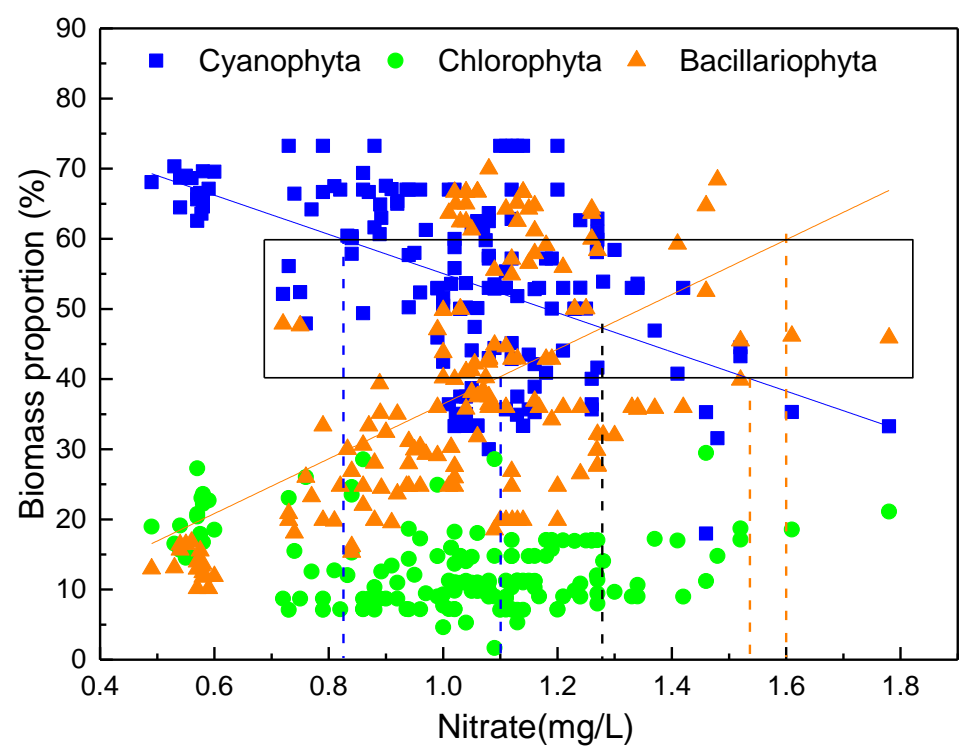

Figure 9. Effects of $\mathrm{NO}_{3}-\mathrm{N}$ on the competitiveness of cyanobacteria and bacillariophyta

Figure 10 shows when COD was $1.20 \sim 1.50 \mathrm{mg} / \mathrm{L}$, the proportion of cyanobacteria and bacillariophyta was $30 \% \sim 72 \%$. When COD was $1.38 \mathrm{mg} / \mathrm{L}$, the proportion of cyanobacteria and bacillariophyta were both equal to $49 \%$. The competition between them was fierce and neither had obvious advantages. With the increase of COD, the dominance of bacillariophyta declined while the dominance of cyanobacteria increased. When COD was $1.82 \mathrm{mg} / \mathrm{L}$, the proportion of bacillariophyta dropped below $40 \%$, losing dominance, while the proportion of cyanobacteria rose further. When COD was $2.55 \mathrm{mg} / \mathrm{L}$, the proportion of cyanobacteria was over $60 \%$. Cyanobacteria completely occupied the dominant position, while the diatom proportion dropped to about $20 \%$. From Figure 9, it can be found that the competitiveness of cyanobacteria is significantly higher than that of diatoms at lower nutrient saline levels. With the increase of nutrient concentration, the competitiveness of bacillariophyta increased significantly. This validates the research results of Onur. Cyanobacteria cell sizes are much smaller than diatom cells. Therefore the higher nutrient affinity and growth rate of the small $\mathrm{s}$ Cyanobacteria makes them better competitors (Onur et al., 2012). The linear fitting formula of blue-green algae competitiveness and COD was calculated as Equation 7. The linear fitting formula of diatom competitiveness and COD was calculated as Equation 8. 
$[$ Chla-cyanophyta $]=36.14+9.44 \mathrm{COD}, \mathrm{R}^{2}=0.17$

$[$ Chla-bacillariophyta $]=73.42-18.15 \mathrm{COD}, \mathrm{R}^{2}=0.31$

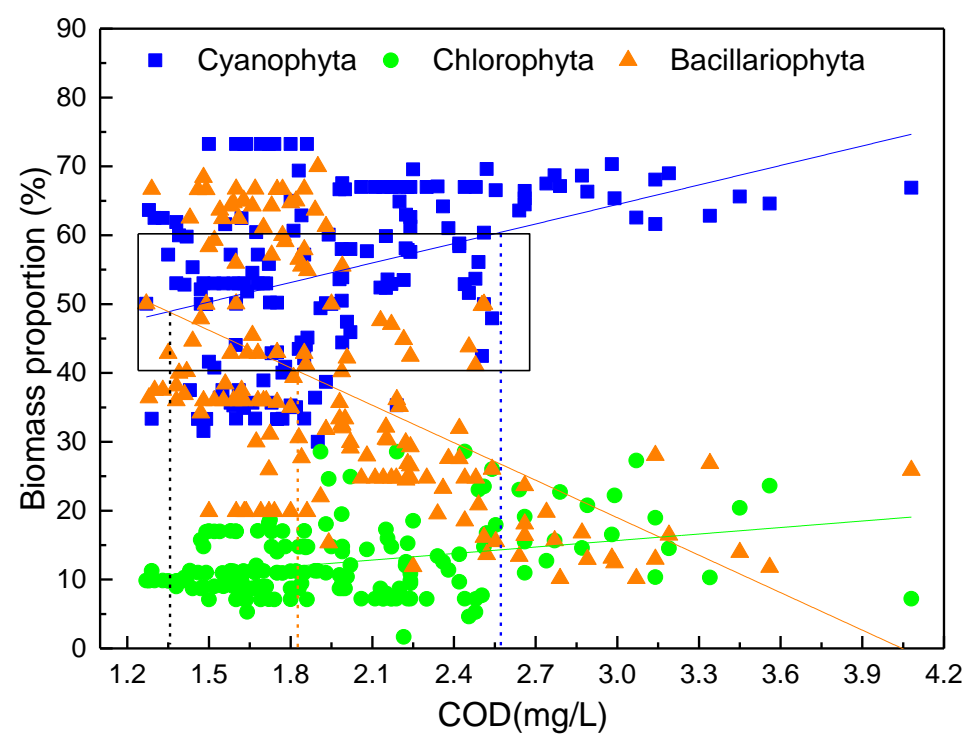

Figure 10. Effects of COD on the competitiveness of cyanobacteria and bacillariophyta

Therefore, environmental factors such as WT, TOC, $\mathrm{NO}_{3}{ }^{-} \mathrm{N}$ and COD were closely related to the competitiveness of cyanobacteria and bacillariophyta. So they can be used as an early warning index for algal bloom. WT $22^{\circ} \mathrm{C}$ can be used as a primary WT threshold of cyanobacteria. When WT was more than $22^{\circ} \mathrm{C}$, the diatom dominance decreased, and the predominance of cyanobacteria rose rapidly. WT $28{ }^{\circ} \mathrm{C}$ can be used as the secondary WT threshold of cyanobacteria. When WT was over $28{ }^{\circ} \mathrm{C}$, and the predominance of cyanobacteria was over $60 \%$, and cyanobacteria blooming was most likely to occur. Similarly, the primary TOC threshold of cyanobacteria was $2.8 \mathrm{mg} / \mathrm{L}$, and the secondary TOC threshold was $4.2 \mathrm{mg} / \mathrm{L}$. The primary $\mathrm{NO}_{3}{ }^{-} \mathrm{N}$ threshold of cyanobacteria was $1.25 \mathrm{mg} / \mathrm{L}$, and the secondary $\mathrm{NO}_{3}^{-}-\mathrm{N}$ threshold was $0.85 \mathrm{mg} / \mathrm{L}$. The primary COD threshold of cyanobacteria was $1.25 \mathrm{mg} / \mathrm{L}$, and the $\mathrm{t}$ secondary COD threshold was $2.55 \mathrm{mg} / \mathrm{L}$.

Analysis of the effects of dual environmental factors on the competitiveness of cyanobacteria and bacillariophyta

The effects of single environmental factors on the competitiveness of cyanobacteria and bacillariophyta were analyzed in the previous section (Figs. 11-14). However, in the real environment of the reservoir, the growth of algae was influenced by synergistic effect of many environmental factors. WT was the most important environmental factor. Therefore, the dual synergistic effects of WT and other environmental factors on the competitiveness of cyanobacteria and bacillariophyta were further analyzed. Bubble charts were used and bubble size indicated the proportion of chl-a to cyanobacteria or bacillariophyta, which represented the competitiveness of cyanobacteria and bacillariophyta. 

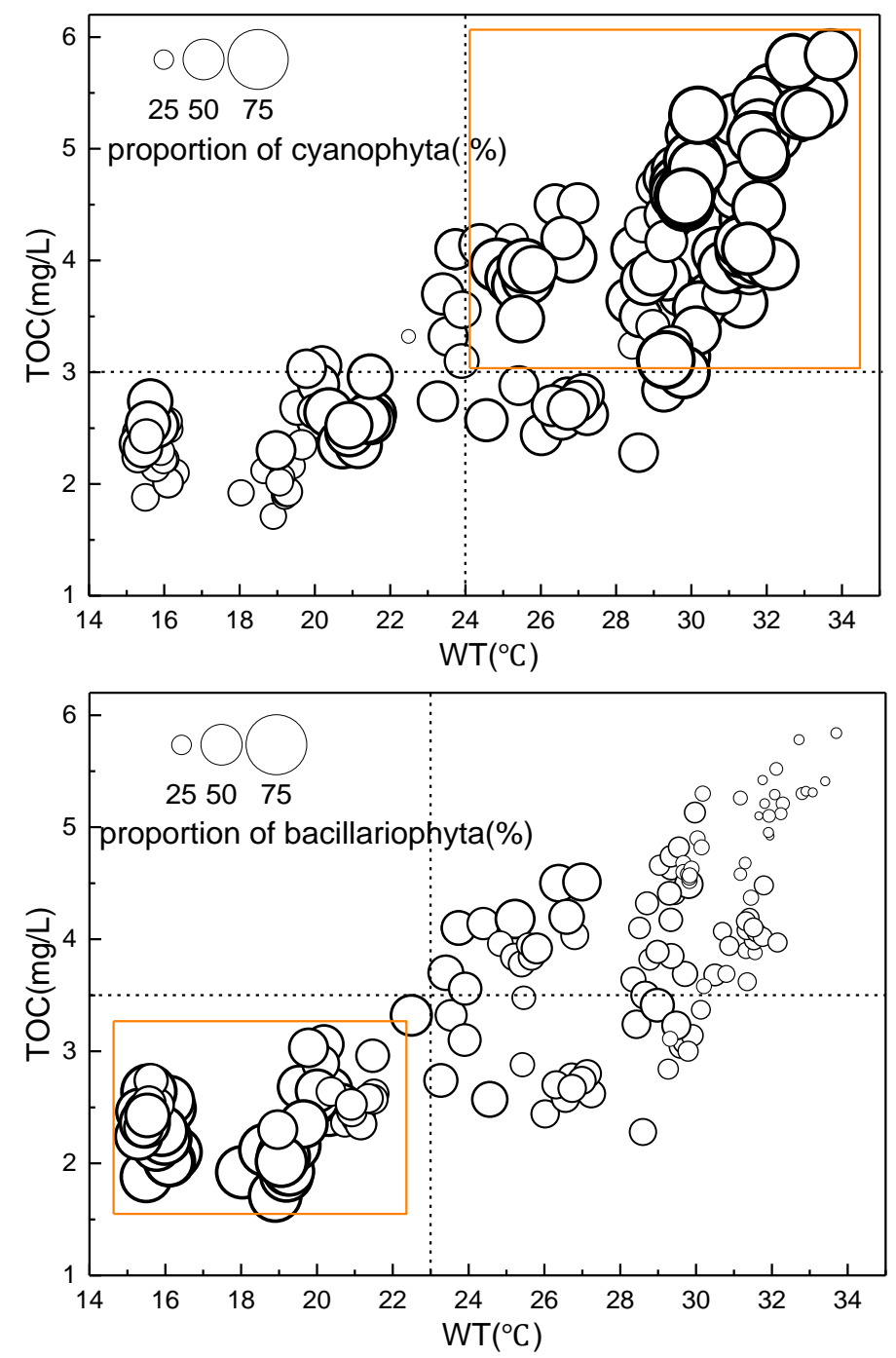

Figure 11. Combined effects of WT and TOC on the competitiveness of cyanobacteria and bacillariophyta

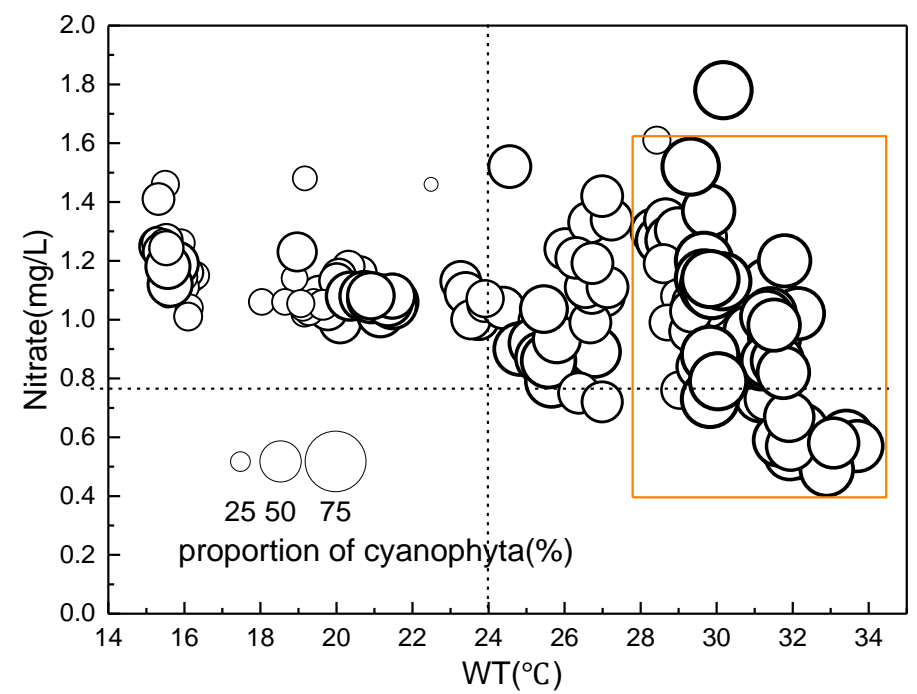




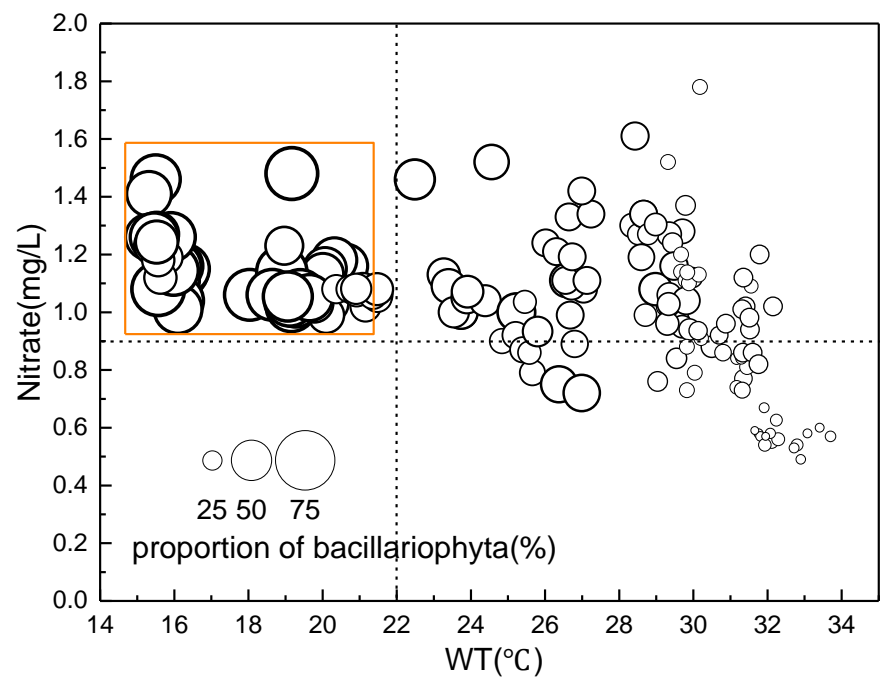

Figure 12. Combined effects of WT and $\mathrm{NO}_{3}{ }^{-} \mathrm{N}$ on the competitiveness of cyanobacteria and bacillariophyta
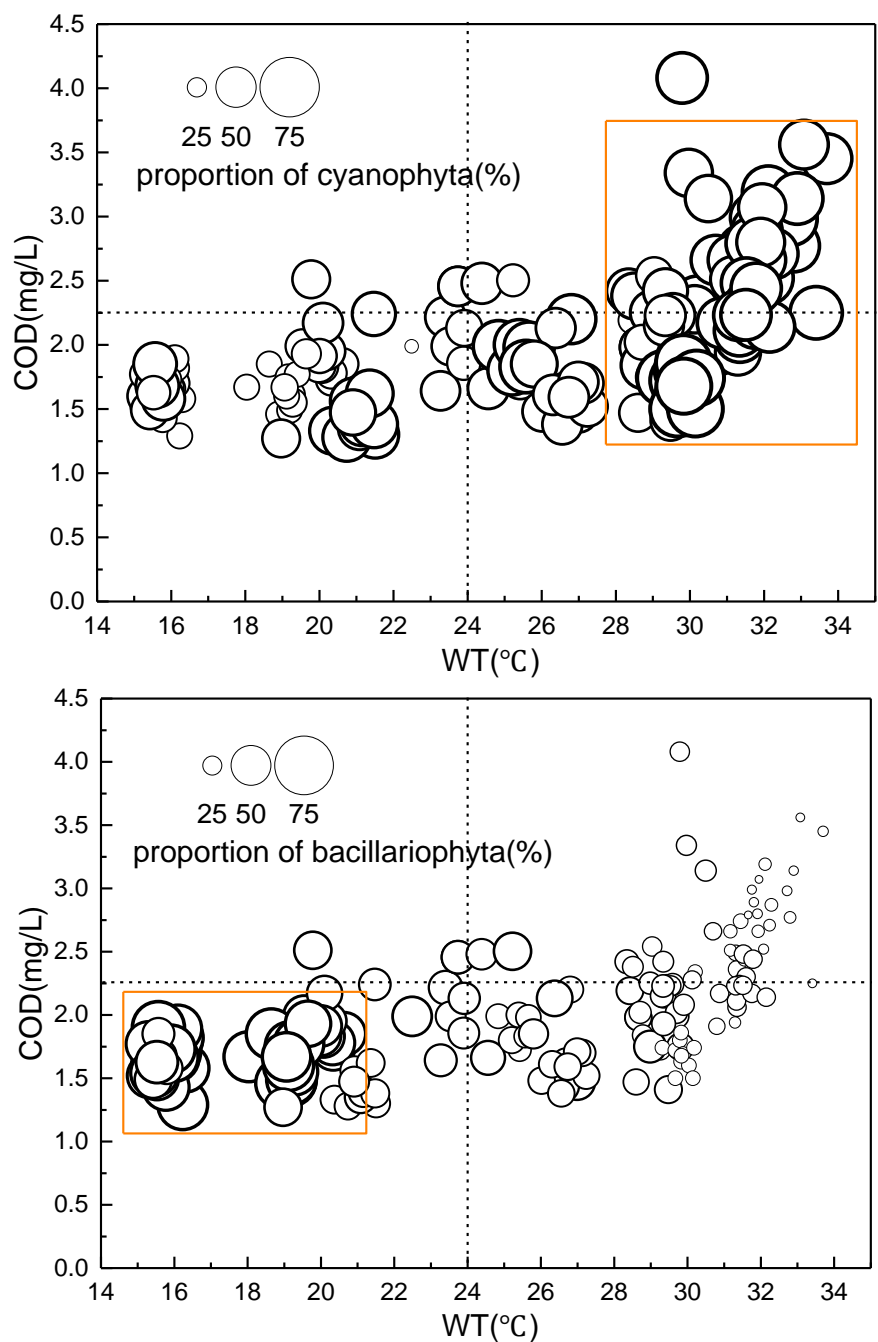

Figure 13. Combined effects of WT and COD on the competitiveness of cyanobacteria and bacillariophyta 

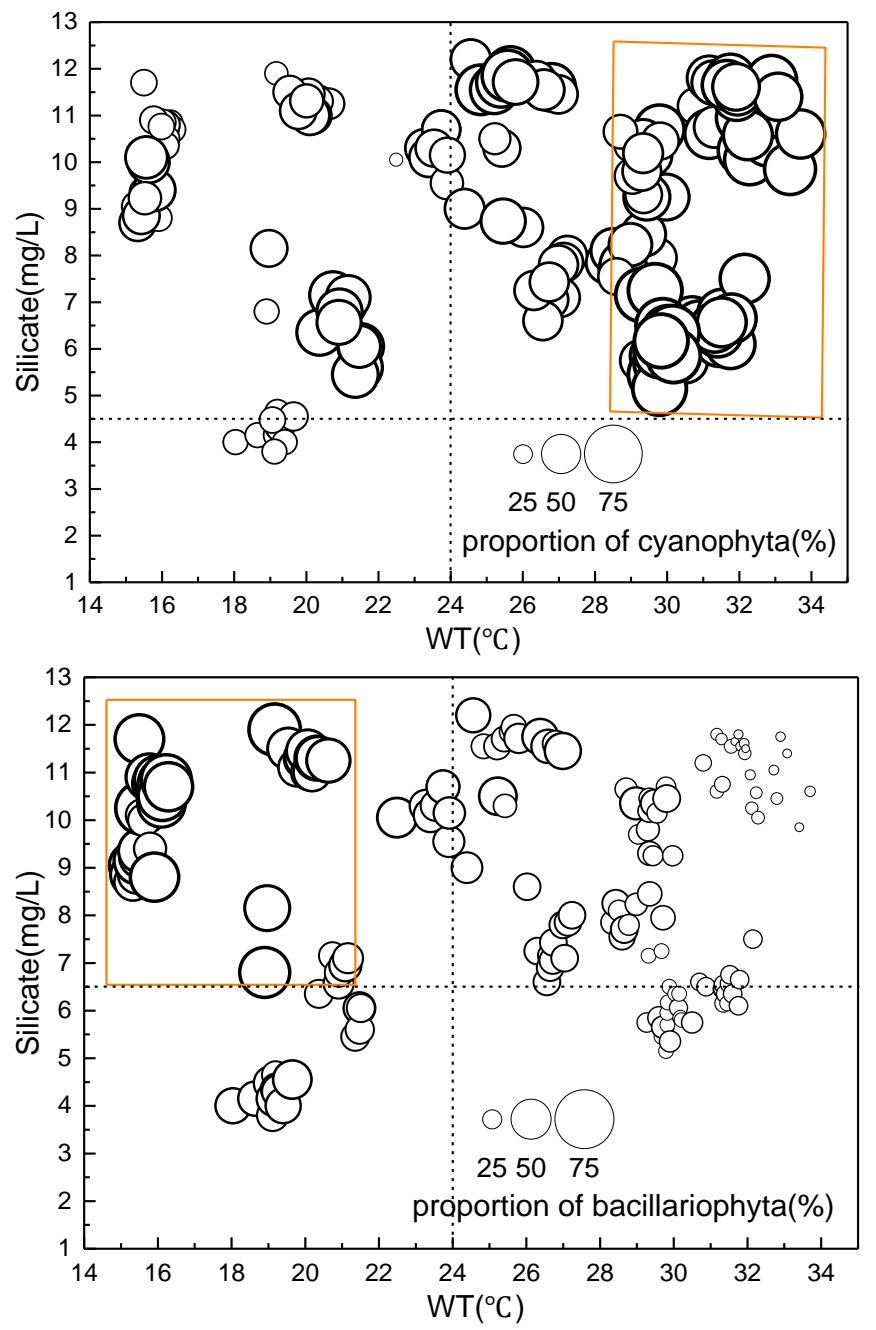

Figure 14. Combined effects of Silicate and $\mathrm{NO}_{3}{ }^{-} \mathrm{N}$ on the competitiveness of cyanobacteria and bacillariophyta

A combination of environmental factors at high risk for cyanobacteria or diatoms were found. WT $\left(24.5 \sim 33.5^{\circ} \mathrm{C}\right)$ and TOC $(3.2 \sim 5.8 \mathrm{mg} / \mathrm{L})$ were high risk factors for cyanobacteria outbreaks. WT $\left(15.5 \sim 21.5^{\circ} \mathrm{C}\right)$ and TOC $(1.5 \sim 3.3 \mathrm{mg} / \mathrm{L})$ were high risk factors for bacillariophyta outbreaks. WT $\left(28.5 \sim 33.5^{\circ} \mathrm{C}\right)$ and $\mathrm{NO}_{3}{ }^{-} \mathrm{N}(0.5 \sim 1.5 \mathrm{mg} / \mathrm{L})$ were high risk factors for cyanobacteria outbreaks. WT $\left(15.5 \sim 21.5^{\circ} \mathrm{C}\right)$ and $\mathrm{NO}_{3}{ }^{-} \mathrm{N}$ $(1.0 \sim 1.5 \mathrm{mg} / \mathrm{L})$ were high risk factors for bacillariophyta outbreaks. WT $\left(28.5 \sim 33.5^{\circ} \mathrm{C}\right)$ and COD $(1.7 \sim 3.5 \mathrm{mg} / \mathrm{L})$ were high risk factors for cyanobacteria outbreaks. WT $\left(15.5 \sim 20.5^{\circ} \mathrm{C}\right)$ and COD $(1.2 \sim 1.9 \mathrm{mg} / \mathrm{L})$ were high risk factors for bacillariophyta outbreaks. WT $\left(28.5 \sim 33.5^{\circ} \mathrm{C}\right)$ and Silicate $(5.0 \sim 11.8 \mathrm{mg} / \mathrm{L})$ were high risk factors for cyanobacteria outbreaks. WT $\left(15.5 \sim 20.5^{\circ} \mathrm{C}\right)$ and Silicate $(6.5 \sim 12.0 \mathrm{mg} / \mathrm{L})$ were high risk factors for bacillariophyta outbreaks.

\section{Conclusions}

1) During the monitoring period, the average connection of algae $[\rho$ (TChla)] in

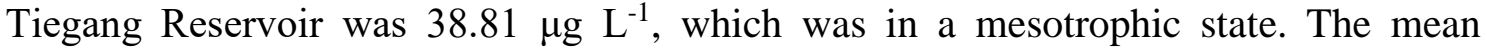


$\rho$ (Chla) values of cyanobacteria, bacillariophyta and chlorophyta were $22.74,11.53$ and $4.54 \mu \mathrm{g} \mathrm{L}^{-1}$, respectively. From late December 2013 to early 2014, bacillariophyta was the dominant algae (46.37-61.81\%), cyanobacteria was dominant in all other periods (48.13-72.58\%), and chlorophyta was low throughout the entire year (7.25-14.80\%). Compared with the same period of the previous year, the proportion of cyanobacteria was increased in the period of May-June 2014, and the proportions of bacillariophyta and chlorophyta decreased with the decreased diversity of algae, leading to the increased risk of a cyanobacteria bloom.

2) The temporal changing pattern of $\rho(\mathrm{Chla})$ in Tiegang Reservoir is as follows: the early rainy season $>$ the late rainy season $>$ the high temperature and no rain period $>$ the temperature rising period $>$ the autumn and winter water storage period. The distribution of $\rho(\mathrm{Chla})$ in the vertical direction is as follows: the transparent layer $>$ the surface layer $>$ the bottom layer. The spatial changing pattern of $\rho(\mathrm{Chla})$ is a gradual increase from southeast to northwest. The No. 9 and No. 10 sampling sites are at the entry of the runoff to the reservoir, whose $\rho($ Chla) were significantly higher than that in other reservoir areas. The water quality of the No. 2 sampling site at the intake point of the water plant was good. The northwest reservoir area is at high risk of an algal bloom.

3) Pearson correlation analysis and CCA analysis showed that the spatio-temporal distribution of algae was mainly driven by changes in climate, for which the WT was the primary driving factor. The main environmental factors for cyanobacteria, bacillariophyta and chlorophyta were greatly different. Cyanobacteria is mainly associated with WT, TOC, sunshine hours, runoff and HRT; bacillariophyta is mainly associated with WT, silicate, TN, TP and HRT; and chlorophyta are mainly associated with TOC, $\mathrm{COD}, \mathrm{WT}, \mathrm{NO}_{3}{ }^{-}-\mathrm{N}$ and sunshine hours.

4) Influence of environmental factors on the competitiveness of cyanobacteria and bacillariophyta was analyzed. Single environmental factors such as WT, TOC, $\mathrm{NO}_{3}{ }^{-} \mathrm{N}$, and COD were significantly related to the competitiveness of cyanobacteria and bacillariophyta. The linear fitting formula of cyanobacteria competitiveness and environmental factors were calculated. The dual synergistic effects of WT and other environmental factors on the competitiveness of cyanobacteria and bacillariophyta were analyzed. A combination of environmental factors with high risk of cyanobacteria and diatom outbreaks was proposed.

Acknowledgements. This study was founded by the Special Funds for Public Industry Research Projects of the National Ministry of Water Resources (201301047) and Shenzhen Science and Technology Innovation Project (JCYJ20140508155916418).

\section{REFERENCES}

[1] Abell, J. M., Hamilton, D. P. (2015): Biogeochemical processes and phytoplankton nutrient limitation in the inflow transition zone of a large eutrophic lake during a summer rain event. - Ecohydrology 8: 243-262.

[2] Beecraft, L., Watson, S. B., Smith, R. E. H. (2017): Multi-wavelength pulse amplitude modulated fluorometry (Phyto-PAM) reveals differential effects of ultraviolet radiation on the photosynthetic physiology of phytoplankton pigment groups. - Freshwater Biology 62: 72-86. 
[3] Bell, P. R. F., Elmetri, I., Lapointe, B. E. (2014): Evidence of large-scale chronic eutrophication in the great barrier reef: quantification of chlorophyll a thresholds for sustaining coral reef communities. - AMBIO 43: 361-376.

[4] Bernal-Brooks, F. W., Sánchez Chávez, J. J., Bravo Inclán, L. et al. (2016): The algal growth-limiting nutrient of lakes located at Mexico's Mesa Central. - Journal of Limnology 75: 169-178.

[5] Bott, T. L., Montgomery, D. S., Arscott, D. B., Dow, C. L. (2006): Primary productivity in receiving reservoirs: links to influent streams. - Journal of the North American Benthological Society 25: 1045-1061.

[6] Bowes, M. J., Gozzard, E., Johnson, A. C. et al. (2012): Spatial and temporal changes in chlorophyll-a concentrations in the River Thames basin, UK: are phosphorus concentrations beginning to limit phytoplankton biomass? - Science of the Total Environment 426: 45-55.

[7] Davis, T. W., Berry, D. L., Boyer, G. L., Gobler, C. J. (2009): The effects of temperature and nutrients on the growth and dynamics of toxic and non-toxic strains of Microcystis during cyanobacteria blooms. - Harmful Algae 8: 715-725.

[8] Eisner, L. B., Gann, J. C., Ladd, C. et al. (2016): Late summer/early fall phytoplankton biomass (chlorophyll a) in the eastern Bering Sea: spatial and temporal variations and factors affecting chlorophyll a concentrations. - Deep Sea Research Part II: Topical Studies in Oceanography 134: 100-114.

[9] Fadel, A., Atoui, A., Lemaire, B. J., Vinçon-Leite, B., Slim, K. (2015): Environmental factors associated with phytoplankton succession in a Mediterranean reservoir with a highly fluctuating water level. - Environmental Monitoring and Assessment 187: 1-14.

[10] Gu, P., Ma, X. (2013): Investigation and analysis of a floating population's settlement intention and environmental concerns: a case study in the Shawan River Basin in Shenzhen, China. - Habitat International 39:170-178.

[11] Güneralp, B., Seto, K. C. (2008): Environmental impacts of urban growth from an integrated dynamic perspective: a case study of Shenzhen, South China. - Global Environmental Change 18: 720-735.

[12] Jakob, T., Schreiber, U., Kirchesch, V. et al. (2005): Estimation of chlorophyll content and daily primary production of the major algal groups by means of multiwavelengthexcitation PAM chlorophyll fluorometry: performance and methodological limits. Photosynth Res 83: 343-61.

[13] Jung, S. W., Youn, S. J., Shin, H. H. et al. (2013): Effect of temperature on changes in size and morphology of the marine diatom, Ditylum brightwellii (West) Grunow (Bacillariophyceae). - Estuarine, Coastal and Shelf Science 135: 128-136.

[14] Lee, Y. J., Matrai, P. A., Friedrichs, M. A. M. et al. (2015): An assessment of phytoplankton primary productivity in the Arctic Ocean from satellite ocean color/in situ chlorophyll-a based models. - Journal of Geophysical Research Oceans 120: 6508.

[15] Li, T., Wang, N., Li, S. (2015): Preliminary investigation of radon concentration in surface water and drinking water in Shenzhen City, South China. - Radiation Protection Dosimetry 167: 59-64.

[16] Liu, L., Ma, X. (2011): Integrated river basin management in rapidly urbanizing areas: a case of Shenzhen, China. - Frontiers of Environmental Science \& Engineering in China 5: 243-254.

[17] Liu, X., Feng, J. F., Wang, Y. Q. (2019) Chlorophyll a predictability and relative importance of factors governing lake phytoplankton at different timescales. - Science of the Total Environment 648: 472-480.

[18] Liu, Z. H., Wang, Y. L., Li, Z. H., Peng, J. (2013): Impervious surface impact on water quality in the process of rapid urbanization in Shenzhen, China. - Environmental Earth Sciences 68: 2365-2373. 
[19] Lu, S., Zhang, H., Sojinu, S. O., Liu, G. et al. (2015): Trace elements contamination and human health risk assessment in drinking water from Shenzhen, China. - Environmental Monitoring and Assessment 187(1): 4220.

[20] Mantyla, A. W., Bograd, S. J., Venrick, E. L. (2008): Patterns and controls of chlorophyll-a and primary productivity cycles in the Southern California Bight. - Journal of Marine Systems 73: 48-60.

[21] Mitrovic, S. M., Hitchcock, J. N., Davie, A. W., Ryan, D. A. (2010): Growth responses of Cyclotella meneghiniana (Bacillariophyceae) to various temperatures. - Journal of Plankton Research 32: 1217-1221.

[22] Molisani, M. M., Becker, H., Barroso, H. S., Hijo, C. A. et al. (2011): The influence of Castanhao reservoir on nutrient and suspended matter transport during rainy season in the ephemeral Jaguaribe River (CE, Brazil). - Braz J Biol 73: 115-23.

[23] Morin, A., Lamoureux, W., Busnarda, J. (1999): Empirical models predicting primary productivity from chlorophyll a and water temperature for stream periphyton and lake and ocean phytoplankton. - Freshwater Science 18: 299-307.

[24] Mowe, M. A. D., Porojan, C., Abbas, F., Mitrovic, S. M. et al. (2017): Corrigendum to Rising temperatures may increase growth rates and microcystin production in tropical Microcystis species. - Harmful Algae 63: 205-206.

[25] Naeher, S., Suga, H., Ogawa, N. O. et al. (2016): Compound-specific carbon and nitrogen isotopic compositions of chlorophyll a and its derivatives reveal the eutrophication history of Lake Zurich (Switzerland). - Chemical Geology 443: 210-219.

[26] Ng, C. N., Xie, Y. J., Yu, X. J. (2011): Measuring the spatio-temporal variation of habitat isolation due to rapid urbanization: a case study of the Shenzhen River cross-boundary catchment, China. - Landscape and Urban Planning 103: 44-54.

[27] Nishijima, W., Umehara, A., Sekito, S. et al. (2016): Spatial and temporal distributions of Secchi depths and chlorophyll a concentrations in the Suo Nada of the Seto Inland Sea, Japan, exposed to anthropogenic nutrient loading. - Science of the Total Environment 571: 543-550.

[28] O Neil, J. M., Davis, T. W., Burford, M. A., Gobler, C. J. (2012): The rise of harmful cyanobacteria blooms: the potential roles of eutrophication and climate change. Harmful Algae 14: 313-334.

[29] Okumura, C., Rahman, M. A., Takimoto, A., Hasegawa, H. (2013): Effect of nitrate on the determination of iron concentration in phytoplankton culture medium by liquid scintillation counting (LSC) method using 55Fe as radioisotope tracer. - Journal of Radioanalytical and Nuclear Chemistry 296: 1295-1302.

[30] Onur, K., Dietmar, S., Frank, P. (2012): Role of phytoplankton cell size on the competition for nutrients and light in incompletely mixed systems. - Journal of Theoretical Biology 300: 330-343.

[31] Pinckney, J. L., Quigg, A. S., Roelke, D. L. (2017): Interannual and seasonal patterns of estuarine phytoplankton diversity in Galveston Bay, Texas, USA. - Estuaries and Coasts 40: 310-316.

[32] Pyo, J., Ha, S., Pachepsky, Y. A., Lee, H. et al. (2016): Chlorophyll-a concentration estimation using three difference bio-optical algorithms, including a correction for the low-concentration range: the case of the Yiam reservoir, Korea. - Remote Sensing Letters 7: 407-416.

[33] Qin, H. P., Su, Q., Khu, S. T. (2014): Water quality changes during rapid urbanization in the Shenzhen River catchment: an integrated view of socio-economic and infrastructure development. - Sustainability 6(10): 7433-7451.

[34] Russo, A. D. P. G., de Souza, M. S., Mendes, C. R. B. et al. (2015): Photophysiological effects of Fe concentration gradients on diatom-dominated phytoplankton assemblages in the Antarctic Peninsula region. - Journal of Experimental Marine Biology and Ecology 466: 49-58. 
[35] Smith, V. H. (1983): Low nitrogen to phosphorus ratios favor dominance by blue-green algae in lake phytoplankton. - Science 221: 669-671.

[36] Sugie, K., Nishioka, J., Kuma, K. et al. (2013): Availability of particulate Fe to phytoplankton in the Sea of Okhotsk. - Marine Chemistry 152: 20-31.

[37] Tachibana, A., Nishibe, Y., Fukuda, H. et al. (2017): Phytoplankton community structure in Otsuchi Bay, northeastern Japan, after the 2011 off the Pacific coast of Tohoku Earthquake and tsunami. - Journal of Oceanography 73: 55-65.

[38] Tebbs, E. J., Remedios, J. J., Harper, D. M. (2013): Remote sensing of chlorophyll-a as a measure of cyanobacterial biomass in Lake Bogoria, a hypertrophic, saline-alkaline, flamingo lake, using Landsat ETM+. - Remote Sensing of Environment 135: 92-106.

[39] Teeter, A. M., Johnson, B. H., Berger, C. et al. (2001): Hydrodynamic and sediment transport modeling with emphasis on shallow-water, vegetated areas (lakes, reservoirs, estuaries and lagoons). - Hydrobiologia 444: 1-23.

[40] Terauchi, G., Tsujimoto, R., Ishizaka, J., Nakata, H. (2014): Preliminary assessment of eutrophication by remotely sensed chlorophyll-a in Toyama Bay, the Sea of Japan. Journal of Oceanography 70: 175-184.

[41] Tian, W., Zhang, H., Zhao, L. et al. (2017): Phytoplankton diversity effects on community biomass and stability along nutrient gradients in a Eutrophic Lake. International Journal of Environmental Research 14: 1-15.

[42] van Ruth, P. D., Ganf, G. G., Ward, T. M. (2010): The influence of mixing on primary productivity: A unique application of classical critical depth theory. - Progress in Oceanography 85: 224-235.

[43] Wainger, L., Yu, H., Gazenski, K., Boynton, W. (2016): The relative influence of local and regional environmental drivers of algal biomass (chlorophyll-a) varies by estuarine location. - Estuarine, Coastal and Shelf Science 178: 65-76.

[44] Wu, Y., Li, L., Gan, N., Zheng, L. et al. (2014): Seasonal dynamics of water bloomforming Microcystis morphospecies and the associated extracellular microcystin concentrations in large, shallow, eutrophic Dianchi Lake. - Journal of Environmental Sciences 26: 1921-1929.

[45] Zhou, H., Shi, P., Wang, J., Yu, D., Gao, L. (2011): Rapid urbanization and implications for river ecological services restoration: case study in Shenzhen, China. - Journal of Urban Planning \& Development 137: 121-132.

[46] Zhu, D. W., Wu, S. Z., Han, J. C. (2018): Evaluation of nutrients and heavy metals in the sediments of the Heer River, Shenzhen, China. - Environmental Monitoring and Assessment 190(7): 380. 